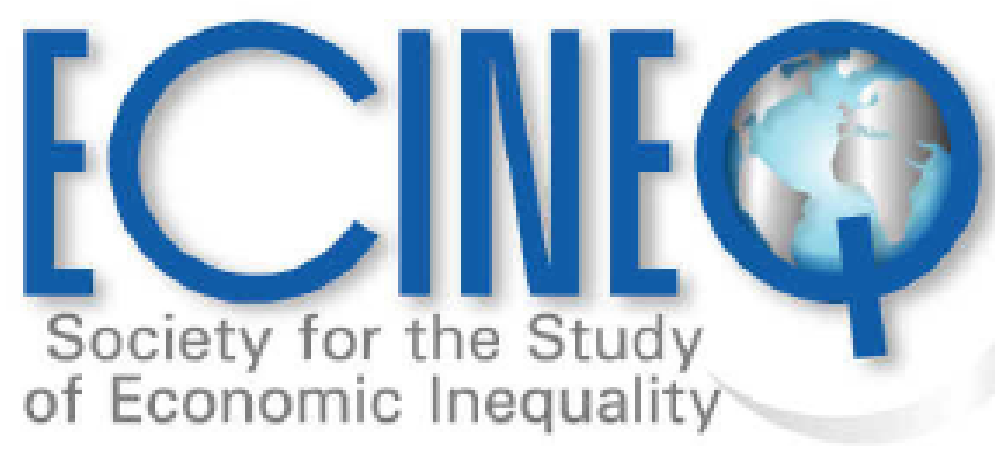

Working Paper Series

\title{
Political connections and the super-rich in Poland
}

Katarzyna Salach

Michal Brzezinski 


\title{
ECINEQ 2020553
}

2020 July

www.ecineq.org

\section{Political connections and the super-rich in Poland}

\author{
Katarzyna Salach \\ University of Warsaw \\ Michal Brzezinski \\ University of Warsaw
}

\begin{abstract}
We use newly collected original panel data on the super-wealthy individuals in Poland (observed over 2002-2018) to study the impact of the rich's political connections on their wealth level, mobility among the rich and the risk of dropping off the rich list. The multimillionaires are classified as politically connected if we find reliable news stories linking their wealth to political contacts or questionable licenses, or if a person was formerly an informant of communist Security Service or member of the communist party, or when the origins of wealth are connected to the privatization process. We find that political connections are not associated with the wealth level of Polish multimillionaires, but that they are linked to the 20-30\% lower probability of upward mobility in the ranking of the rich. Moreover, being a former member of the communist party or secret police informant increases the risk of dropping off the Polish rich list by $79 \%$. Taken together, our results show that, contrary to some other post-socialist countries such as Russia or Ukraine, there is little evidence that the Polish economy suffers from crony capitalism.
\end{abstract}

Keyword: the super-rich, oligarchs, political connections, crony capitalism, Poland.

JEL Cassification: D31, D63, P36. 


\title{
Political connections and the super-rich in Poland ${ }^{*}$
}

\author{
Katarzyna Sałach ${ }^{1}$, Michał Brzeziński ${ }^{2}$
}

\begin{abstract}
We use newly collected original panel data on the super-wealthy individuals in Poland (observed over 2002-2018) to study the impact of the rich's political connections on their wealth level, mobility among the rich and the risk of dropping off the rich list. The multimillionaires are classified as politically connected if we find reliable news stories linking their wealth to political contacts or questionable licenses, or if a person was formerly an informant of communist Security Service or member of the communist party, or when the origins of wealth are connected to the privatization process. We find that political connections are not associated with the wealth level of Polish multimillionaires, but that they are linked to the 20-30\% lower probability of upward mobility in the ranking of the rich. Moreover, being a former member of the communist party or secret police informant increases the risk of dropping off the Polish rich list by $79 \%$. Taken together, our results show that, contrary to some other post-socialist countries such as Russia or Ukraine, there is little evidence that the Polish economy suffers from crony capitalism.
\end{abstract}

Keywords: the super-rich, oligarchs, political connections, crony capitalism, Poland

JEL: D31, D63, P36

\footnotetext{
* Financial support of the Polish National Science Centre through grant no. UMO-2017/25/B/HS4/01360 is gratefully acknowledged. We would like to thank Lee Benham, Katrina Kosec and the participants of the Eight ECINEQ Meeting (Paris, 2019), The Ronald Coase Institute Workshop on Institutional Analysis (Warsaw, 2019), the ECSR 2nd Thematic Workshop "Wealth Inequality and Mobility" (Luxembourg, 2018) and 29th Conference of the Faculty of Economic Sciences, University of Warsaw (Chęciny, 2018) for their insightful comments.

${ }^{1}$ Faculty of Economic Sciences, University of Warsaw. E-mail: ksalach@wne.uw.edu.pl. Corresponding author.

${ }^{2}$ Faculty of Economic Sciences, University of Warsaw. E-mail: mbrzezinski@wne.uw.edu.pl.
} 


\section{Introduction}

Recent research on wealth inequality, largely sparked by Thomas Piketty's (2014) Capital in the Twenty-First Century, shows that disparities in wealth are rapidly increasing globally. Top $1 \%$ wealth share increased in the United States from around $25-30 \%$ in the 1980 s to around $40 \%$ in 2016, and from about $28 \%$ in 1980 to $33 \%$ today in China, Europe and the United States combined (Zucman 2019). Wealth shares of the richest seem to be growing particularly fast. According to the Forbes 400 Richest Americans list, the share of total wealth in the US-owned by the top $0.00025 \%$ (the richest 400 Americans) of the population has grown from $1 \%$ in the early 1980s to more than 3\% in recent years (Zucman 2019). Over the 1987-2017 period, the richest $0.01 \%$ in the US, Europe and China combined have seen their wealth increasing by $5.6 \%$ per year, while the average wealth of the top $1 \%$ grew by $3.5 \%$ per year (and by $2.8 \%$ for the whole population). Alvarado et al. (2018) estimate that if the current trends in wealth inequality were to be sustained, the top $0.1 \%$ on the global level will own more wealth than the world middle class by 2050. The share of world billionaires coming from transition and emerging countries has been increasing rapidly reaching 42\% in 2014 (Freund 2016). These numbers have led to the rise of substantial research interest on the determinants and consequences of growing fortunes of the super-rich (Keister 2014; Bagchi and Svejnar 2015, 2016; Medeiros and de Souza 2015; Hay and Beaverstock 2016; Freund 2016; Korom et al. 2017). However, these issues are still understudied, especially in the context of newly advanced or emerging economies.

What are the sources of the greatest fortunes and what factors help the rich to protect or improve their extraordinary position among the other super-rich? In this paper, we attempt to shed light on this issue by investigating the factors that are associated with the multimillionaires' wealth level, mobility in the ranking of the rich, and the likelihood of dropping off the ranking of the richest individuals. We focus on Poland - a post-socialist emerging economy, which is widely perceived as the poster child of a successful transition to the market economy and “Europe's growth champion” (World Bank 2017; Piątkowski 2018). We pay special attention to political connections as a factor explaining the size of multimillionaires' fortunes, their mobility and chances of survival among the richest. By this, we study if the Polish economy has become a crony capitalist one in which plutocrats exploit political connections to secure financial success, stifle competition, and impede the process of being outcompeted by unconnected entrepreneurs. Several recent studies have found that political connections played an important role in amassing and defending oligarchic great fortunes in Russia and Ukraine (Braguinsky 2009; Markus and Charnysh 2017; Lamberova and Sonin 2018). While the Polish 
super-wealthy are not oligarchs as they are not powerful enough to affect institutional changes in the fields of politics, regulation or judiciary (Guriev and Rachinsky 2008), it is still possible that their political connections help perpetuate or expand their fortunes.

The salience of super-rich cronies has recently been highlighted by Bagchi and Svejnar (2015), who have shown that politically-connected wealth inequality is detrimental to economic growth globally (while the effect of unconnected wealth inequality is insignificant, as they argue). Moreover, Fidrmuc and Gundacker (2017) demonstrated that the presence of oligarchs, who have often become rich through privatization rigged towards politically-connected individuals (Guriev and Rachinsky 2005), significantly increases income inequality in Russian regions. Fidrmuc and Gundacker (2017) obtained that while social capital in terms of informal network strength and trust is significantly higher in Russian regions with stronger oligarchic presence, trust in the family and the quality of public governance (especially at the local government level) tends to be evaluated as significantly worse. These works suggest that economic growth and social progress may be threatened when the largest fortunes arise due to ties with the political sphere or when they are protected by the politicians from the shocks resulting from changing market conditions.

In this paper, we use the rich lists published yearly by the Polish magazine Wprost. The earliest available year is 2002, thus we focus on the period 2002-2018. We complement the ranks and wealth estimates by a set of manually collected variables, including personal characteristics, wealth characteristics and three indicators related to political connections. We follow the literature (see, e.g., Bagchi and Svejnar 2015, 2016; Freund 2016) in classifying a person as strictly politically connected if reliable news stories are connecting her wealth to past positions in government, close relatives or friends in government, or questionable licenses. Bearing in mind a specific context of a post-socialist country, we also treat as politically connected the multimillionaires who under socialism served as Security Service informants or were members of the communist party. In addition, all super-rich persons who had their fortunes originated in privatized firms are classified as politically connected as we were unable to identify rigorously which privatization decisions after 1989 were dictated by political favours to insiders and cronies.

Contrary to our expectations, we find no evidence for the beneficial effect of political connectedness. None of the variables capturing political connections of Polish multimillionaires is consistently related neither to the size of the largest fortunes in Poland nor to the chances of upward mobility on the rich list. Moreover, we find evidence that being a former secret police informant or a former member of the communist party contributes to a greater likelihood of 
completely falling off the rich list. We compare our results with those for Russia and Ukraine and point to the possible explanations for our findings, seeking for them in the differing circumstances of transformation from centrally-planned to a market economy in Central and Eastern Europe and in the Post-Soviet States.

The remainder of the paper is structured as follows. Section 2 provides a review of literature on the origins of post-communist oligarchy in Russia and lack of it in Poland. It describes privatization processes and highlights the importance of institutions in establishing a market economy. It also reviews the literature that seeks to explain the number of billionaires in a cross-country setting. Section 3 gives a detailed description of our variables and presents the first insights from descriptive analysis. Section 4 introduces our methodology, while section 5 presents and discusses the results. The last section concludes.

\section{The literature on the super-rich}

Why oligarchy does not have to be a rule in a post-transition country? The vast literature documents the emergence of oligarchy in countries like Russia and Ukraine after fall of communism in the early 1990s (e.g. Braguinsky 2009; Guriev and Rachinsky 2005, 2008; Markus and Charnysh 2017; Earle et al. 2019). The term "oligarch", as Havrylyshyn (2006) rightly notes, is widely used with relation to the richest of Russia and CIS countries, but rarely to name the richest from Central and Eastern Europe. It denotes an extra-wealthy person who controls sufficient resources to influence national politics in favour of himself (the female oligarchs are almost non-existent) ${ }^{3}$. This is far more than lobbying or even rent-seeking, which includes obtaining government privileges, but is smaller in scale, regards influencing only specific politics and not general policy. Mihályi and Szelényi (2019) argue that in postcommunist countries rent-seeking works differently than in advanced liberal democracies and that in some circumstances it can lead to "state capture by oligarchs". ${ }^{4}$ The major circumstance in this context was the mass privatization of state enterprises that started in the early 1990s in almost all transition countries of the region. The details of the process, however, differed substantially between the countries and are now blamed for the success of some of them (i.e. virtual non-existence of oligarchy) and lack of thereof in others. In Russia, voucher

\footnotetext{
${ }^{3}$ Braguinsky (2009) studies in detail 296 first-wave post-communist oligarchs in 1995 and finds only 7 women. Guriev and Rachinsky's (2005) study of Russian oligarchs as of summer 2003 does not include any women at all. ${ }^{4}$ Although in the next step, due to political elites being on the counter-attack, it may lead to an "oligarch capture by political elites". According to many authors, it has actually happened in Russia after 2000, under the presidency of Vladimir Putin (Mihályi and Szelényi, 2019; Monday, 2017). Lamberova and Sonin (2018) find a positive and significant effect of direct connections to the personal circle of President Putin on the wealth of businessmen.
} 
privatization in the years 1992-1994 and "loans-for-shares" scheme in 1995-1996 finally resulted in the concentration of wealth in the hands of the few. Although Braguinsky (2009) argues that among the first-wave of post-transition oligarchs only $43 \%$ were insiders, i.e. the members of the privileged nomenklatura including "red directors" of the Soviet period, he instantly notes that the overwhelming majority of the outsiders subsequently developed their own relationships with the government. Braguinsky concludes that although the outsiders were younger, better educated and started their businesses in the sectors neglected in the centrallyplanned economy, instead of changing the rules of the game, they were themselves changed by the rules.

The privatization in Poland had also a quick start but due to public resistance large enterprises were in practice not privatized until $1996 .{ }^{5}$ Piątkowski (2018) claims that delays in the privatization of large enterprises turned out to be lucky for Poland. First, the country could learn from voucher privatization in the Czech Republic and Russia, limit the number of state enterprises being mass-privatized and choose different privatization methods. Second, it was easier to properly establish the value of state enterprises in the middle of 1990s than right after the fall of communism. Third, Poland gained time to create and strengthen market institutions (Piątkowski, 2018).

This does not mean that the reforms in Poland were slow. It was just the opposite: Poland was the first to begin the transition and to start stabilization (IMF 2000) and Leszek Balcerowicz's reforms are commonly referred to as "shock therapy". ${ }^{6}$ In this sense, it is in line with Havrylyshyn's (2006) thesis that a late start and gradual reforms increased the probability of "state capture" because delayed and partial economic liberalization created rent-seeking opportunities. We argue that this probability has been minimalised in Poland.

The importance of institutions in establishing a market economy is widely recognised in the literature (e.g. Acemoglu and Robinson 2012; Piątkowski 2018; Havrylyshyn 2006). The rule of law and security of property rights create an environment not only for private business growth but also indirectly for the well-being of all members of society. Guriev and Rachinsky (2008) note, in the context of former the Soviet Union and Central and Eastern Europe, that privatization has increased personal wealth inequality, especially in countries that lagged in building effective institutions. They also suggest that in Russia and other Post-Soviet states

\footnotetext{
${ }^{5}$ Up to 1995 , only $13 \%$ of large industrial plants were privatized (Berend, 2011). On the contrary, small enterprises were privatized quickly.

${ }^{6}$ Leszek Balcerowicz was Polish Deputy Prime Minister and Minister of Finance during 1989-1991 period (and also from 1997 to 2000) and authored the so-called "Balcerowicz Plan", the comprehensive set of economic reforms which aimed at transitioning Poland to a market economy.
} 
overall wealth inequality was probably amplified by the rise of oligarchs and specific features of privatization processes in these countries. Hoff and Stiglitz (2004) build a theoretical model of mass privatization of state enterprises, in which they try to explain the gap between what emerged in the 1990s (in Russian context) and what the reformers hoped would emerge. They show that asset stripping can cripple the demand for the rule of law. There is no foundation to expect that creating mass private ownership through privatization would automatically lead to establishing market institutions.

The pace and mode of privatization was not the only factor to be blamed for the emergence of oligarchy in some countries. Havrylyshyn (2006) lists at least three other broad vehicles: 1) direct budget subsidies for state enterprises; 2) borrowing from the government at low interest rates in times of hyperinflation; 3 ) the possibility of buying energy and other natural resources at still-controlled low prices and reselling them at far higher market prices. The extent to which these factors were present during the early years of economic transformation likely influenced its outcome in terms of the emergence of the politically-connected super-rich.

There is also a list of possible positive explanations for why a country like Poland managed not to create a class of oligarchs. First, the expectation of accession to the European Union created a credible commitment to secure property rights. It also indicated that the rewards to rent-seeking would decrease to the EU level, thus the agents were encouraged to engage in more productive activities instead (Roland 2018). Second, Poland is culturally closer to Western Europe than e.g. Ukraine, both historically and geographically (Piątkowski 2019). Third, the lack of already mentioned huge natural resources diminished the potential for rent-seeking. Fourth, the strength of civil society played a role. Roland (2018) argues that the maturity of dissident activities in the 1980s influenced political institutions that were chosen after the collapse of communism. In Poland, Czechoslovakia and the Baltic states dissident movements against the communist regime were present for years and were ready for roundtable negotiations when the time came. Contrary, in most of the Former Soviet Union civil society was not prepared for discovering overnight that the Communist Party that has ruled for more than 70 years was now outlawed. This created opportunity for the former nomenklatura, which was also stronger and more united in these states than in the CEE, to shape institutions towards strong presidential executive powers and low judicial independence (Roland 2018).

Political connections of the super-rich were more formally defined by Bagchi and Svejnar (2015) using news sources from around the world. They have classified members of the Forbes World Billionaires list as politically connected if a member would not have become a billionaire in the absence of government favouritism or support. An important result from the 
Bagchi and Svejnar's (2015) paper is that politically connected wealth inequality has a negative impact on economic growth, politically unconnected wealth inequality (as well as income inequality and poverty) are not correlated with the GDP growth. Using the same definition of political connections, Freund (2016) has conducted an extensive analysis of billionaire wealth in emerging markets. She found that the share of politically connected billionaire wealth in emerging markets grew from $21 \%$ in 2001 to $29 \%$ in 2014 (in advanced economies the share increased from 0.7 to $2.6 \%$ over the same period). Markus and Charnysh (2017) analysed strategies of the Ukrainian oligarchs to protect their wealth against shocks. They have found that strategies of party support and media ownership significantly enhance oligarchs' wealth, but that holding a government position by an oligarch does not affect their wealth.

Leaving political connections aside, with this paper we also add to the large body of literature on the origins of largest fortunes. Starting with the pioneering contributions of John Siegfried and his co-authors (Siegfried and Roberts 1991; Siegfried and Round 1994), this literature has sought to identify sources of the richest persons' wealth. The articles within this strand are exploiting data on super-rich wealth compiled by business magazines such as Forbes, with the Forbes 400 Richest Americans and the Forbes World's Billionaires being the most popular data sets used. Most of the studies investigate how the variability of the largest fortunes can be accounted for by individual characteristics of the super-rich such as age, gender, educational background, self-made versus inherited status of wealth, sector from which wealth originates, etc. In particular, the role of inheritance has been studied in detail in several works (Canterbery, Ray and Nosari 1985; Kaplan and Rauh 2013; Freund 2016). The evidence summarized by Freund (2016) suggests that inheritance has become less important for the very wealthy in the US in the last three decades but remains the most influential factor in Europe and other advanced countries. Kaplan and Rauh (2013) argue that the declining role of inheritance for the richest Americans, coupled with an increased impact of education and technology-related sources of super-rich wealth, provide evidence for the skill-biased technological change as the basic mechanism explaining fast growth of the top wealth values in the US.

Related literature seeks to explain the number of billionaires in a cross-country setting using macro-level explanatory variables such as the GDP per capita level, population, stock market capitalization, interest and tax rates, and others. Using Forbes data averaged over 20012003, Neumayer (2004) found that the number of billionaires per country is positively related to the level of property rights protection, population and the GDP per capita, but not correlated with government interventionism, the fiscal burden, trade openness and the level of social 
protection. Prinz (2016) has confirmed a positive and statistically significant relationship between the number of billionaires on the one hand and protection of property rights and the GDP per capita on the other hand in a cross-section of 142 countries. His results show also that various institutional variables derived from the Economic Freedom Index such as indicators of trade freedom, labour freedom and monetary freedom are not related to the number of billionaires per country. Using data from the Forbes 2008 World's Billionaires List, Treisman (2016) established a positive correlation between country's frequency of billionaires and its market size (GDP per capita, population, stock market capitalization), and low top marginal income tax rates. The relationships with natural resources rents and rule of law were insignificant, while high real interest rates and proceeds from privatization over 1990-2008 emerged surprisingly as negatively related to the number of billionaires.

\section{Data}

\subsection{Overview of rich lists' data}

A starting point for our analysis are the lists of the richest Poles published yearly by Wprost magazine. The rich lists provide us with names, ranks, wealth estimates and sometimes industry. Our data span over 17 years, starting in 2002, which is the earliest year available. We are concerned with personal wealth, so in the case of families, couples, or siblings we divide the total wealth between them (the rich lists are sometimes inconsistent and in some years treat family members separately, and in other years jointly). This is why our final lists of the richest differ from the original ones. We end up with a database of 1,700 person-years, consisting of 266 different persons. 52 multimillionaires (20\%) appeared only once on the rich list and 17 $(6 \%)$ are listed through the entire 17-year period. The median number of years a person stays on the list is 4.5 and the mean is $6.4 .^{7}$ Figure 1 presents the distribution of the total number of years on the list and the percentage of dropouts each year. The latter rages between $6 \%$ and $29 \%$.

\footnotetext{
${ }^{7}$ These do not have to be consecutive years. There are a few cases of dropouts and comings back, so in these cases we just sum up all years of person's presence on the lists.
} 
Figure 1. Distribution of the total number of years on the list (left panel) and the percentage of dropouts each year (right panel)
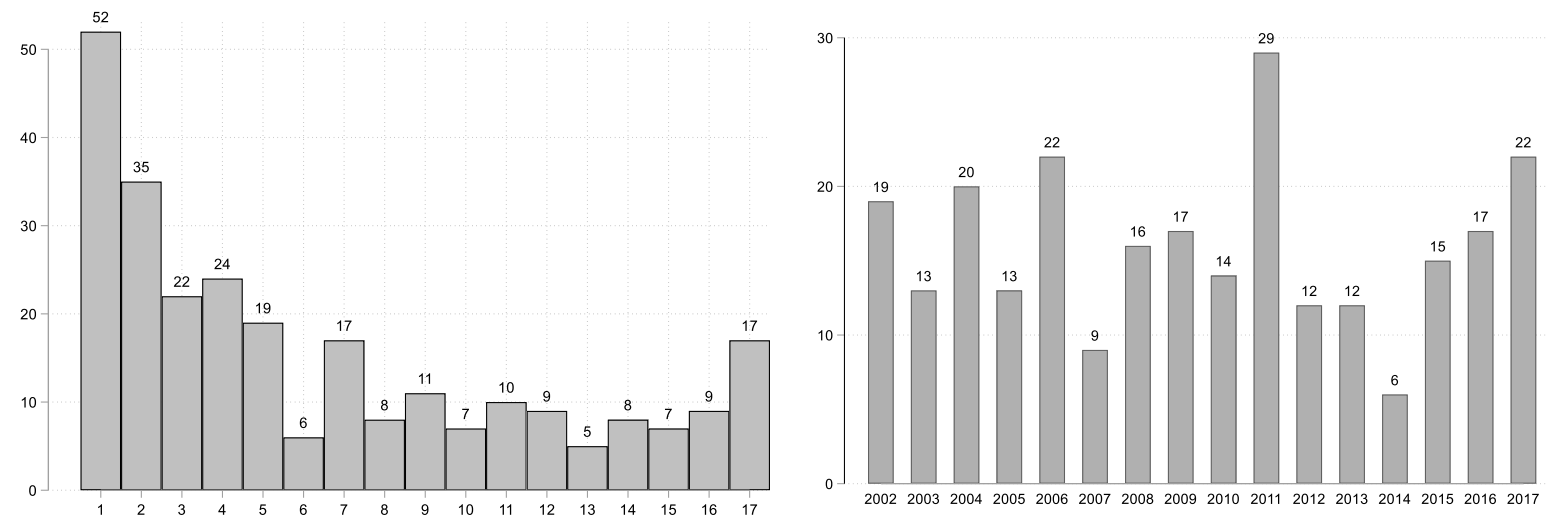

Note: The number of entries on the rich list each year is 100 , so the absolute numbers shown on the right panel are also percentages.

Source: Own calculations based on Wprost 2002-2018 data.

Wealth estimates provided by Wprost magazine base on journalists' investigation of the value of assets. Admittedly, mostly business assets are covered, whereas the coverage of personal wealth such as private real estates, art and private financial investments is limited. The data from rich lists is therefore imperfect, but since it is the only available source of information on top of the top wealth, it is widely used by researchers. ${ }^{8}$ We express all wealth values in inflationadjusted real terms in 2018 prices. Figure 2 displays the evolution of mean and median wealth of one hundred the richest Poles from 2002 to 2018 . The minimum value of wealth needed to make an entry on the rich list increased from PLN 280 million (USD 77.6 million) in 2002 to PLN 340 million (USD 94.2 million) in $2018 .^{9}$

Our first dependent variable is the real level of wealth of all rich persons that appeared on the Wprost rich list between 2002 and 2018. We also study the multimillionaires' mobility on the rich list. Following Korom et al. (2017), we define dependent variable mobility as the yearly difference in ranking between the current and the previous year, with positive numbers indicating upward moves and negative numbers denoting downward ones. If there happens to be a dropout and a later re-entry to the list, we code it simply as the difference in ranking between the current year and the last ranked position before the dropout. Again following

\footnotetext{
${ }^{8}$ For example, Forbes data have been used by Piketty (2014) to estimate trends in wealth inequality in the US from 1987 to 2013. It has also been used by e.g. Korom et al. (2017), Treisman (2016), Capehart (2014), Neumayer (2004). Other authors (see, e.g. Hurst et al. 1998; Klevmarken et al. 2003; Vermeulen 2016, 2018; Bach et al. 2018) in order to provide a more complete picture of wealth inequality have combined wealth data from household surveys with data on the largest fortunes compiled by Forbes and other business magazines. A related literature is concerned with testing whether the distribution of largest fortunes follows the Pareto distribution (see, e.g., Klass et al. 2006; Ogwang 2011).

${ }^{9}$ Values in brackets are given in 2018 American dollars, without PPP adjustment.
} 
Korom et al. (2017), we also define upward mobility and downward mobility as binary variables which take on the value 1 if a multimillionaire experiences an upward (or downward, respectively) move in the ranking larger than the median of all yearly upward (or downward) moves.

Figure 2. Mean and median wealth of 100 the richest Poles: trends over time

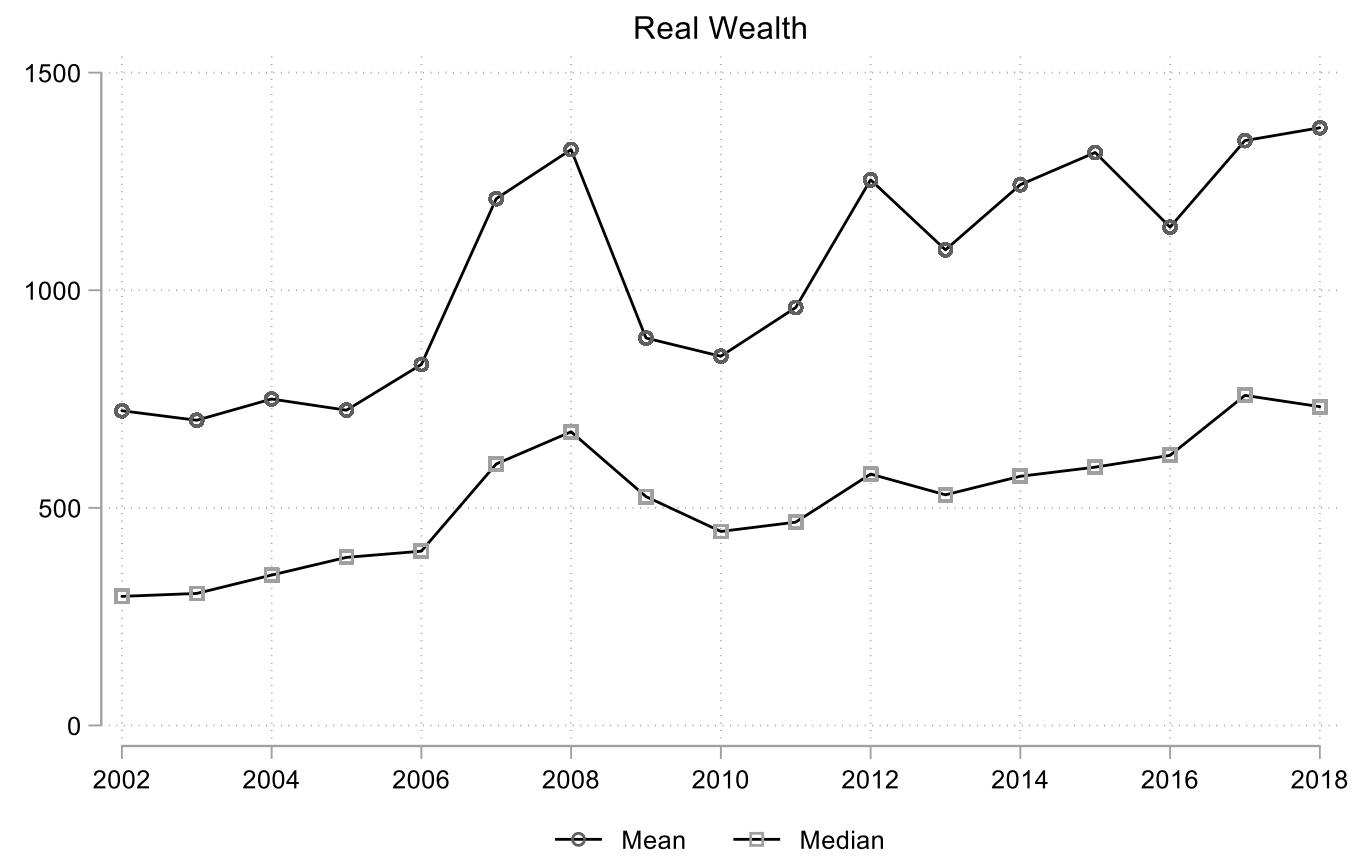

Note: Wealth values are given in millions of Polish zlotys (PLN) and are deflated with CPI 2018. Source: Own calculations based on Wprost 2002-2018 data.

Following the methodology proposed by Freund (2016) and Kaplan and Rauh (2013), we expand the data by adding information on personal and wealth characteristics. We collect them by rigorous internet search. Our predictor and control variables are described in the following subsections and Table A1 in the Appendix presents their descriptive statistics.

\subsection{Predictors}

Our major variable of interest is political connection. It is a binary variable which takes the value of 1 if a person is found to be politically connected. Following Freund (2016), we say that a multimillionaire is politically connected if there are news stories connecting wealth to past positions in government, close relatives or friends in government, or questionable licenses. We collected this information, as well as data on other variables described in this section, from reliable news sources using internet searches. If a person first gathered considerable wealth and 
then e.g. became a politician, then in our sample he or she is not classified as politically connected. There are 13 politically connected individuals in our sample, consisting $5 \%$ of it.

Our second predictor of interest is Security Service. This binary variable takes the value of 1 if under socialism a person served as a Security Service informant or collaborator or was a member of the communist party (the Polish United Workers' Party). ${ }^{10}$ We do not automatically classify all such persons as politically connected and the two groups almost do not overlap: there are $18(7 \%)$ persons with ties to the communist secret police or the communist party in our sample and only three of them are also politically connected in line with the definition above. We consider this variable because it is highly probable that former Security Service informants or communist party members benefitted from acquaintances with politicians, profited from informal networks of ex-nomenklatura members and had special privileges, even if it has never been proved. We stick to our narrow understanding of political connections as defined above to make our study comparable with the existing ones (Freund 2016; Bagchi and Svejnar 2015, 2016). We note, however, that in the context of a post-communist country a broader understanding of political connections may be needed, so this is why we consider additional variables that could potentially capture this.

Third, we code whether a company that is a major source of wealth of a given person was privatized, acquired or new. Again, becoming an owner of a former state enterprise, especially under preferential conditions, could signal political connections. We are not able to unravel the circumstances of every privatization but we hypothesize that it could help to become super-rich. In our empirical analysis, we use this variable as a binary indicator (privatized company) that takes the value of 1 of the company was privatized.

\subsection{Controls}

The list of control variables in our analysis includes gender (female indicator), age and education (higher education indicator, which takes on the value 1 for those who hold Bachelor, Master or PhD degree). The relationship between political connections and wealth may be confounded by the fact that women and men could differ in their ability to make connections with communist political elites which were predominantly male. Age matters because first, we hypothesize that the kind of connections a businessman or businesswoman could make with political elites was different in different periods in the past in Polish modern history, and

\footnotetext{
${ }^{10}$ The Polish United Workers' Party (Polish: Polska Zjednoczona Partia Robotnicza, PZPR) was the communist party which governed the Polish People's Republic from 1948 to 1989.
} 
second, younger people tend to invest in different sectors than older ones (especially so-called "new sectors", i.e. computer and medical technologies), which may affect their returns from investment and as a consequence their wealth. Higher education obtained also influences investment choices. It could also potentially influence the kind of political connections one could make, but this issue is far from obvious. Among other predictors of wealth, we include also:

- started under socialism - a binary indicator showing whether a person started her business already before the transition to the market economy;

- $\quad$ self-made - a dummy variable indicating whether the person's major business was selfmade or inherited;

- four dummy variables (resource related, new sectors, non-traded sectors, financial sectors) corresponding to the sectors of the economy in which the major company of a multimillionaire operates with traded sectors being a reference category. ${ }^{11}$

To capture macroeconomic effects, we include GDP per capita growth rate in all our models. Following Korom et al. (2017), when modelling the probability of dropping off the rich list, we also include the change in mean wealth: the yearly percentage change of mean wealth in the sample from the previous year. We assume that the yearly risk of failure (a dropout) depends not only on individual's wealth but also on the wealth of others and with this variable we are trying to capture whether a millionaire performed better or worse than others. Finally, in this part we also include deceased indicator: for obvious reasons a person who dies drops off the list.

\subsection{Trends in the sources of top wealth and characteristics of the super-rich}

Almost half of the Polish millionaires listed by Wprost magazine operates in traded sectors (Figure 3). At the same time, they are relatively the poorest, with the share of top wealth possessed by them fluctuating around 25\%. A similar share of top wealth is owned by businessmen operating in financial and non-traded sectors. The former, however, consists of $18 \%$ of a sample, when averaged over the years. This suggests that operating in the financial sector brings in general returns higher than average. Figure 3 reveals also increasing importance of new sectors (medical and computer technologies) by the end of the analysed period. At the same time, the importance of those operating in resource-related sectors has been diminishing.

\footnotetext{
${ }^{11}$ New sectors variable includes medical and computer technologies, as well as a business of one person that fitted nowhere else: a super-rich footballer.
} 
Figure 3. Sectoral shares of the richest persons and their wealth

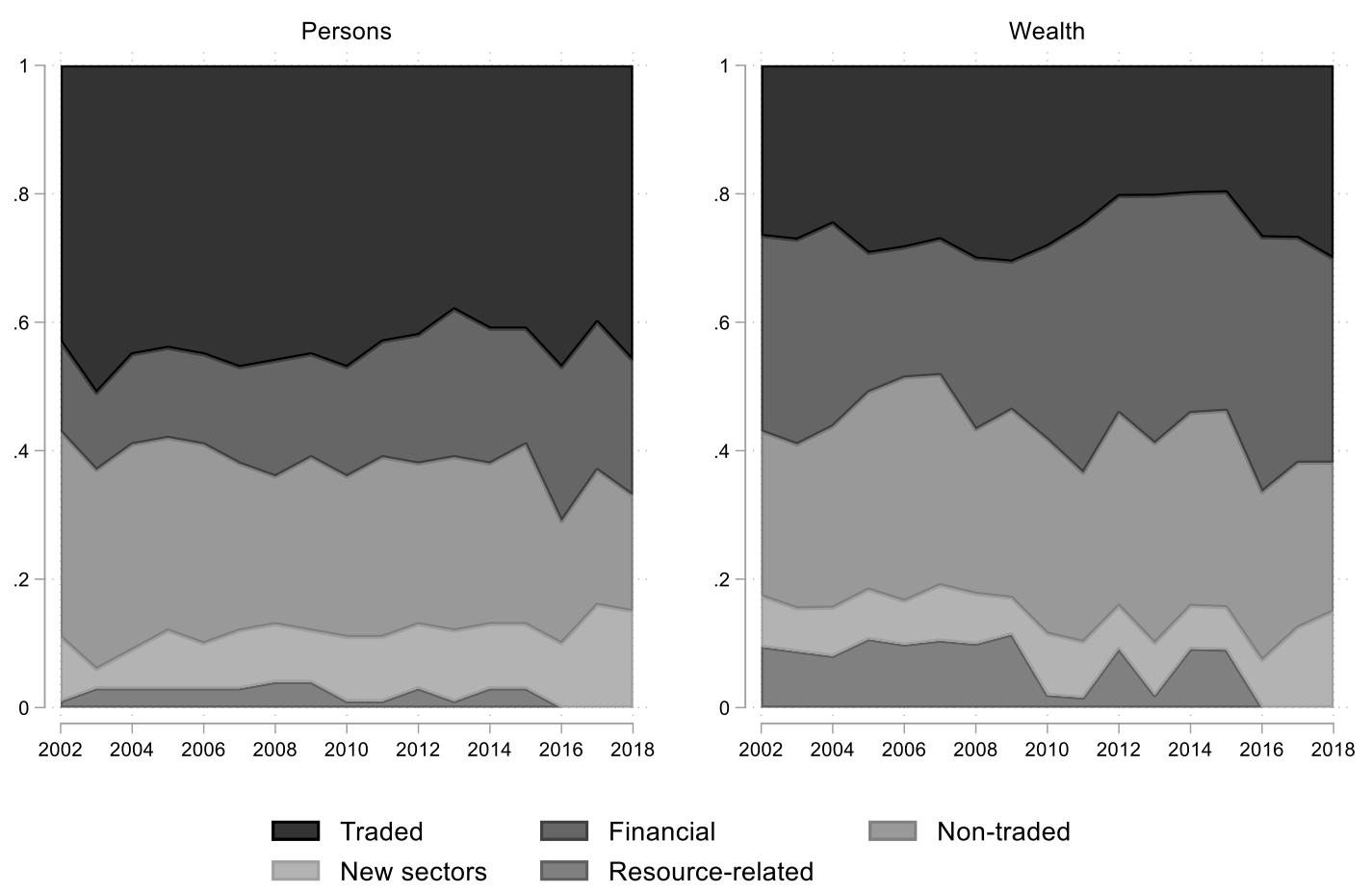

Source: Own calculations based on Wprost 2002-2018 data.

Figures 4 and 5 display the evolution of the shares of top wealth over time according to various characteristics, which we later include in regression models. We can observe a clear increasing pattern in the share of inherited wealth, which rose from $2 \%$ in 2002 to $24 \%$ in $2018^{12}$. A clear increasing pattern can be also observed in the share of female wealth and the mean age of the millionaires: the former rose from $4 \%$ to $16 \%$, the latter from 48 to 56 years. It happened, however, over 17 years, so inexplicitly it confirms a slowly increasing trend of entering younger cohorts into big businesses. Explicitly, this trend can be seen when looking at the share of wealth belonging to those who started their businesses under socialism, that is before 1989: this number dropped from the maximum of $67 \%$ in 2003 to $32 \%$ in 2018 (Figure 5). Holding university degree seems not to display any clear pattern, which is in line with the findings from our models (see Section 5), where we show no significant correlation between this variable and the amount of wealth possessed by the super-rich. The same argument could be repeated regarding wealth share that is connected with privatized companies.

\footnotetext{
12 The big jump between 2015 and 2016 results from a death of Jan Kulczyk, prominent Polish businessman, ranked 1 on the list each year since 2002 until death, except for 2007. In 2016 his children, Dominika and Sebastian, appeared on the list instead of him with a big amount of inherited wealth.
} 
Figure 4. Shares of top wealth according to gender and education characteristics (top panels), the share of inherited wealth (bottom left) and mean age of the millionaires (bottom right)
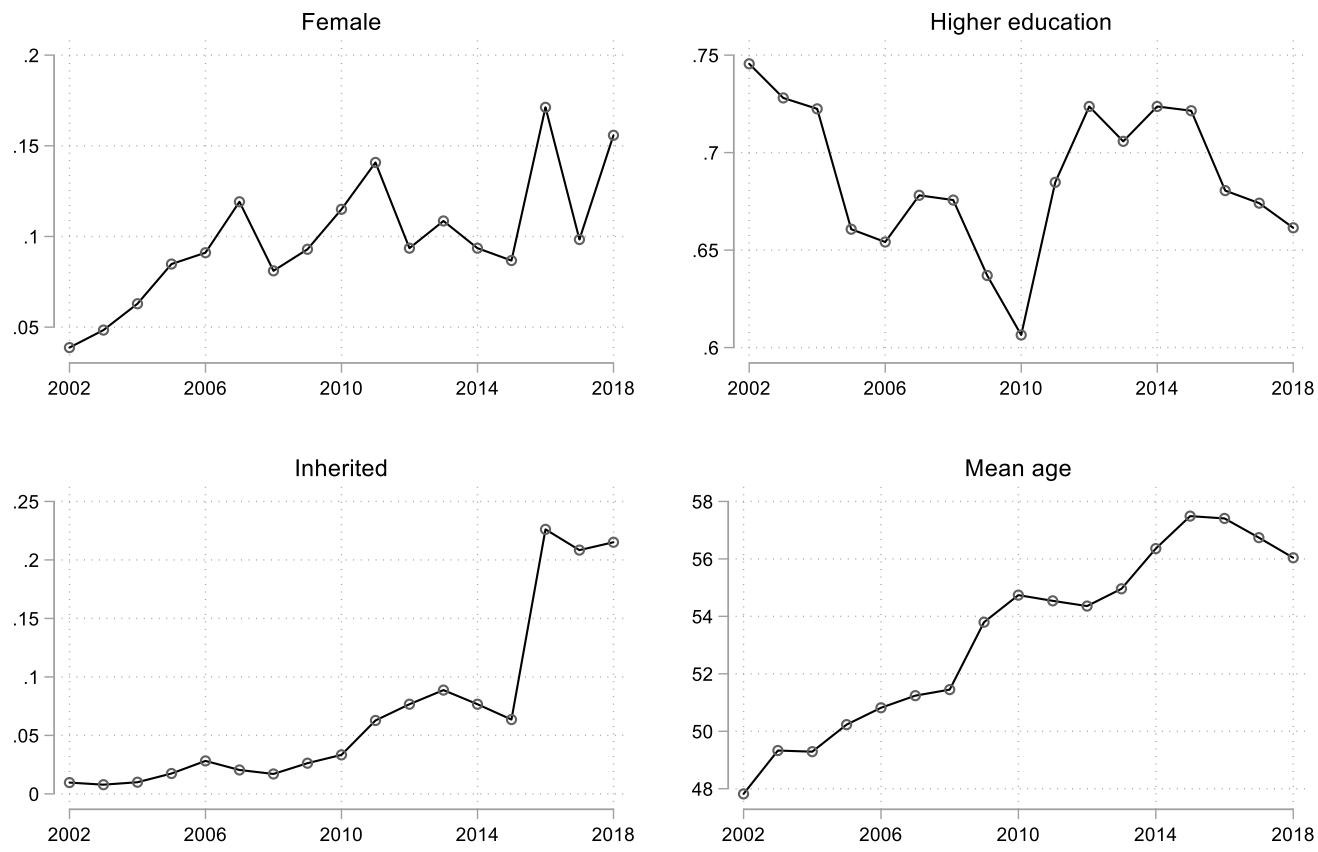

Source: Own calculations based on Wprost 2002-2018 data.

Figure 5. Shares of top wealth according to various characteristics
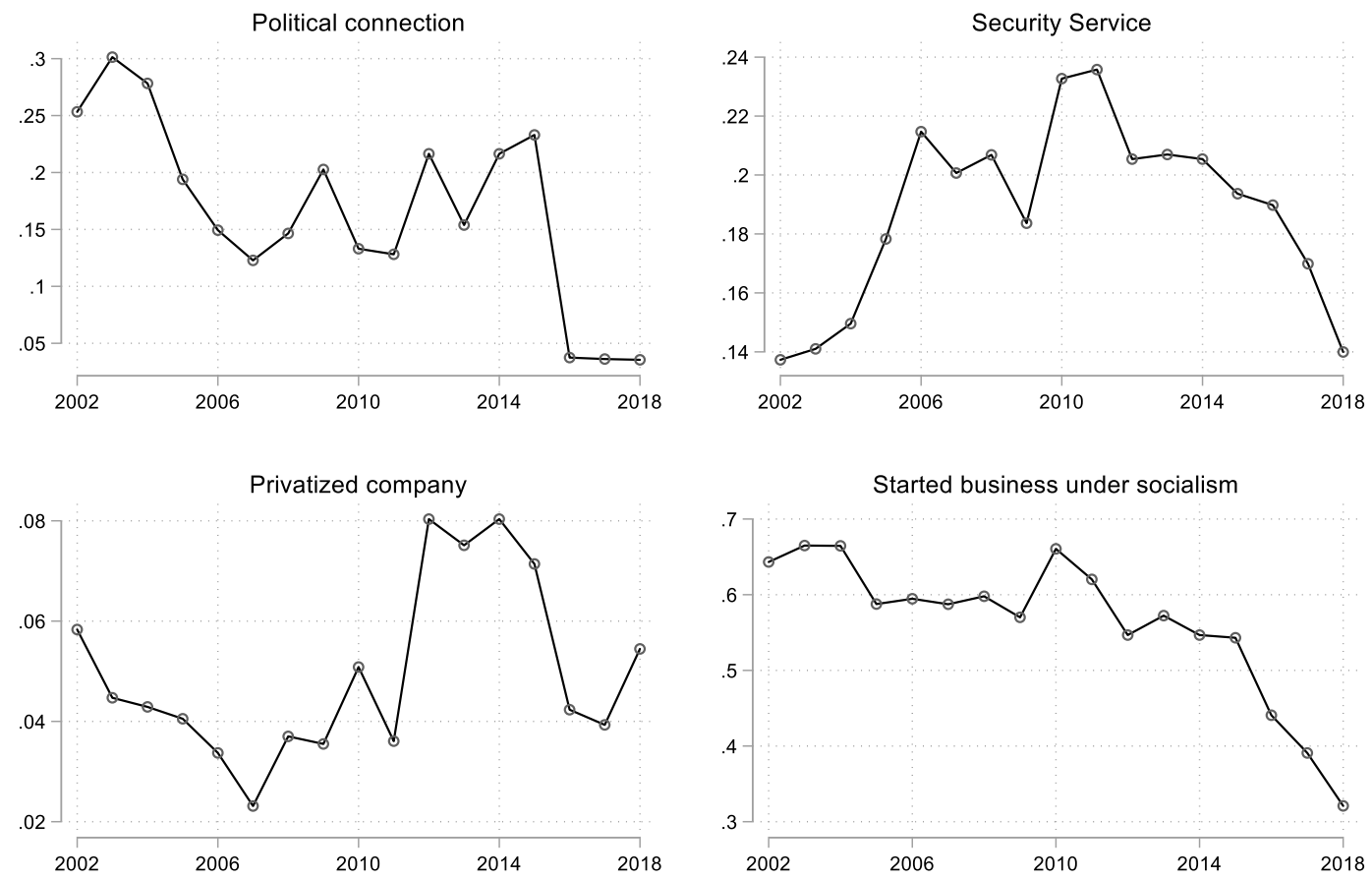

Source: Own calculations based on Wprost 2002-2018 data. 
The share of politically connected wealth decreased from its maximum of $30 \%$ in 2003 to less than $4 \%$ in the years 2016-2018. The over-time pattern in this variable has many fluctuations between its maximum and minimum, but it seems to have stabilized at the low level near the end of the period. The overall trend in politically connected wealth in Poland is opposite to that for all emerging markets, which saw a rise in the share of crony wealth from $21 \%$ in 2001 to 29\% in 2014 (Freund 2016). Finally, the share of wealth possessed by former Security Service informants or members of the communist party displays inverted U-shape with a peak in 2011. Overall, it seems that according to our political connection variable capitalism in Poland has become significantly less crony over time, but less so if we consider the two other dimensions of cronyism.

\section{Methods}

One specific feature of all our three variables related to political connections is that they are predetermined in the sense that they all describe states or processes that occurred under socialism or early after the transformation to market economy started in Poland in 1989. On the other hand, our data on the super-rich's wealth starts only in 2002. Therefore, we can be sure that there is no reverse causality between the types of political connections that our variables capture and the outcome variables that we consider. Another characteristic of our political connection variables is that they are time-invariant. This implies that using a panel structure of our data to estimate the impact of political connections on the wealth of the rich and its persistence is not straightforward. In particular, the standard fixed effects (FE) models, which are the most popular method of panel data estimation that adjusts for the problem of omitted variables bias, cannot be used in our framework as this approach uses only within-panel variation over time and eliminates all time-invariant regressors. ${ }^{13}$ To overcome this problem, in modelling wealth level and mobility of the rich based on panel data we use a recently proposed filtered fixed effects (FEF) estimator (Pesaran and Zhou 2018), which allows estimating coefficients on time-invariant variables. ${ }^{14}$

The FEF estimator, similarly to well-known Hausman-Taylor (1981), HT, procedure, allows for estimating time-invariant effects in static panel data models. ${ }^{15}$ However, contrary to HT, the FEF estimator allows for an arbitrary degree of correlation between the time-varying

\footnotetext{
${ }^{13}$ In our context, the premier example of a omitted variable is unobserved entrepreneurial ability.

14 This estimator is gaining popularity in empirical research. It has been recently used, among others, by Powdthavee et al. (2017) and Candau and Gbandi (2019).

${ }^{15}$ The Hausman-Taylor estimator is an instrumental variables estimator. We cannot use it as we do not have valid instruments for our political connection variables.
} 
covariates and the individual effects. Thus, except for some regularity assumptions, we only need to assume that the time-invariant regressors are uncorrelated with the individual effects.

The FEF estimator works in two steps (Pesaran and Zhou, 2018). First, it computes the coefficients of the time-varying variables and averages over time the residuals from this panel regression. In the second step, these residuals are used as a dependent variable in a cross-section ordinary least squares (OLS) regression that includes an intercept and the vector of timeinvariant regressors. Thanks to this method, the time-varying effects are "filtered out". For comparison purposes, we present also results of the regressions using the OLS and random effects panel models. The latter provide efficient estimates and deliver coefficient estimates for time-invariant variables, but assume that omitted variables are uncorrelated with the model's explanatory variables. If this assumption is not satisfied, which is likely in our case, the random effects models lead to biased estimates. In all models, we estimate standard errors clustered at the individual (person) level.

To estimate the likelihood of dropping off the rich list we use methods from survival analysis, which relates the time before an event occurs to some covariates that are associated with that quantity of time. In our case, we study if political connections increase or decrease the likelihood that the person is falling off the rich list ("failure"). Specifically, we use the Cox proportional hazards model with standard errors clustered by persons and accounting for the right-censoring of the data, since we are unable to identify failures in the last year of observation (2018). Following the work by Korom et al. (2017), who used data from the annual American Forbes 400 ranking (1982-2013) and analysed the importance of inherited vs. self-made wealth in being super-rich, we model multiple failures, because it is possible to drop out of the list, come back several years later and drop out again. To account for multiple failures, we use the marginal risk set model by Wei, Lin, and Weissfeld (1989). It assumes that each failure occurrence for a given person belongs to an independent stratum and estimates the Cox regression with stratified coefficients. In our case, the number of strata equals 5 , because the maximum number of dropouts registered in the data is 4 and there are individuals who have never dropped out. The model ignores the ordering of events, so the individuals are at risk for all events at all times prior to experiencing that event. We take into account the deaths of individuals ( 8 cases) and specify the occurrence of death as an exit time. To handle tied events, i.e. events with the same survival time, we follow the literature in employing the Efron approximation. 


\section{Results and discussion}

\subsection{Are political connections related to the super-rich's wealth in Poland?}

In this section, we study if political connections are positively associated with the level of wealth in our sample of the richest Poles. Table 1 present the results of cross-section and panel regressions with the log of personal wealth as a dependent variable. The independent variables include our three political connection variables and controls such as personal characteristics of the rich persons, an indicator of whether wealth is self-made (and not inherited), a dummy indicating if the multimillionaire started his or her business already under socialism, indicators describing the sectoral classification of the fortunes, and GDP per capita growth. Our preferred results are given by the filtered fixed effects (FEF) model as they, at least partially, adjust for the unobserved time-invariant characteristics of the rich. However, we present also results of the OLS and random effects models to verify if our results depend on the modelling technique. Each model is estimated in two versions: with and without time fixed effects. This allows seeing if our results are robust to economic and other shocks that could have affected all large fortunes at the same time (e.g. stock market booms or crashes).

We start the discussion of results by commenting on control variables. Personal characteristics such as age, gender or education are not significantly related to the wealth level. According to the OLS and random effects models, resource-related wealth and wealth originated in the financial sector is sizeably higher than wealth associated with traded sectors, but this result does not hold when the FEF model is used. On the other hand, random effects and FEF models accounting for time fixed effects suggest that fortunes from new (technological) sectors are higher than those from the traded sectors. For most of the models, GDP per capita growth is positively related to higher wealth. In some cases, we find a negative relationship between the size of the fortune and the fact that the business was started before 1989, but these results are not robust across other modes. Both FEF specifications suggest that self-made multimillionaires are much richer than those who inherited their wealth. This is not surprising since inheritance as a source of large fortunes started to play a significant role in Poland only very recently (see Figure 4). 
Table 1. Determinants of the rich's wealth level in Poland

\begin{tabular}{|c|c|c|c|c|c|c|}
\hline & \multicolumn{2}{|c|}{ Cross-section } & \multicolumn{4}{|c|}{ Panel } \\
\hline & (1) & (2) & (3) & (4) & (5) & (6) \\
\hline & OLS & OLS & $\begin{array}{l}\text { Random } \\
\text { effects }\end{array}$ & $\begin{array}{l}\text { Random } \\
\text { effects }\end{array}$ & $\begin{array}{l}\text { Filtered } \\
\text { fixed } \\
\text { effects }\end{array}$ & $\begin{array}{l}\text { Filtered } \\
\text { fixed } \\
\text { effects }\end{array}$ \\
\hline \multirow{2}{*}{ Privatized company } & -0.148 & -0.109 & -0.186 & -0.017 & -0.101 & -0.085 \\
\hline & $(0.185)$ & $(0.174)$ & $(0.176)$ & $(0.177)$ & $(0.207)$ & $(0.199)$ \\
\hline \multirow{2}{*}{ Political connection } & 0.290 & 0.325 & 0.065 & 0.291 & 0.004 & 0.155 \\
\hline & $(0.337)$ & $(0.354)$ & $(0.329)$ & $(0.308)$ & $(0.368)$ & $(0.372)$ \\
\hline \multirow{2}{*}{ Security Service } & $0.663^{* *}$ & $0.700^{* *}$ & 0.196 & 0.351 & 0.057 & 0.109 \\
\hline & $(0.291)$ & $(0.287)$ & $(0.279)$ & $(0.248)$ & $(0.310)$ & $(0.294)$ \\
\hline \multirow{2}{*}{ Self-made } & -0.279 & -0.048 & $-0.537^{* *}$ & -0.085 & $0.712 * * *$ & $0.409 * * *$ \\
\hline & $(0.207)$ & $(0.168)$ & $(0.259)$ & $(0.160)$ & $(0.041)$ & $(0.057)$ \\
\hline \multirow{2}{*}{ Started under socialism } & -0.072 & 0.022 & $-0.224^{* *}$ & 0.084 & $-0.470 * * *$ & -0.269 \\
\hline & $(0.120)$ & $(0.121)$ & $(0.110)$ & $(0.096)$ & $(0.135)$ & $(0.208)$ \\
\hline \multirow[t]{2}{*}{ Age } & 0.026 & 0.022 & 0.046 & 0.020 & $0.074 *$ & 0.059 \\
\hline & $(0.032)$ & $(0.030)$ & $(0.035)$ & $(0.033)$ & $(0.039)$ & $(0.044)$ \\
\hline \multirow[t]{2}{*}{ Age squared } & -0.000 & -0.000 & -0.000 & -0.000 & -0.000 & -0.000 \\
\hline & $(0.000)$ & $(0.000)$ & $(0.000)$ & $(0.000)$ & $(0.000)$ & $(0.000)$ \\
\hline \multirow[t]{2}{*}{ Female } & -0.177 & -0.104 & -0.205 & -0.072 & 0.079 & 0.033 \\
\hline & $(0.124)$ & $(0.119)$ & $(0.144)$ & $(0.127)$ & $(0.206)$ & $(0.171)$ \\
\hline \multirow[t]{2}{*}{ Higher education } & -0.058 & -0.023 & -0.006 & 0.055 & -0.006 & -0.007 \\
\hline & $(0.130)$ & $(0.123)$ & $(0.106)$ & $(0.087)$ & $(0.132)$ & $(0.115)$ \\
\hline \multirow[t]{2}{*}{ Resource related } & $1.433^{* * *}$ & $1.555^{* * *}$ & $0.773^{* * *}$ & $0.805^{* *}$ & 0.294 & 0.284 \\
\hline & $(0.239)$ & $(0.304)$ & $(0.236)$ & $(0.325)$ & $(0.332)$ & $(0.307)$ \\
\hline \multirow[t]{2}{*}{ New sectors } & 0.218 & 0.151 & $0.433^{* *}$ & 0.291 & 0.661 & $0.722 *$ \\
\hline & $(0.200)$ & $(0.202)$ & $(0.172)$ & $(0.184)$ & $(0.423)$ & $(0.400)$ \\
\hline \multirow{2}{*}{ Non-traded sectors } & 0.189 & 0.203 & 0.166 & 0.128 & 0.215 & 0.246 \\
\hline & $(0.130)$ & $(0.124)$ & $(0.131)$ & $(0.115)$ & $(0.421)$ & $(0.396)$ \\
\hline \multirow[t]{2}{*}{ Financial sectors } & $0.573^{* * *}$ & $0.498^{* *}$ & $0.415^{* *}$ & $0.321^{* *}$ & 0.189 & 0.210 \\
\hline & $(0.204)$ & $(0.204)$ & $(0.166)$ & $(0.148)$ & $(0.336)$ & $(0.307)$ \\
\hline \multirow[t]{2}{*}{ GDP per capita growth } & $0.037^{* * *}$ & $0.327^{* * *}$ & $0.027^{* * * *}$ & $0.272^{* * * *}$ & $0.025 * * *$ & 0.030 \\
\hline & $(0.010)$ & $(0.046)$ & $(0.007)$ & $(0.040)$ & $(0.007)$ & $(0.090)$ \\
\hline \multirow[t]{2}{*}{ Constant } & $5.355^{* * * *}$ & $4.444^{* * *}$ & $4.347^{* * * *}$ & $4.647^{* * * *}$ & - & - \\
\hline & $(0.792)$ & $(0.752)$ & $(0.882)$ & $(0.833)$ & - & - \\
\hline Time fixed effects & No & Yes & No & Yes & No & Yes \\
\hline Observations & 1656 & 1656 & 1656 & 1656 & 1656 & 1656 \\
\hline Number of the rich & 255 & 255 & 255 & 255 & 255 & 255 \\
\hline
\end{tabular}

Notes: Standard errors clustered by person in parentheses. ${ }^{*} p<0.1,{ }^{* *} p<0.05,{ }^{* * * *} p<0.01$. The dependent variable is the log of personal wealth. See Section 3 for definitions of other variables. "Traded sectors" is the reference category for the business sector variable. OLS stands for ordinary least squares. Source: own calculations using 2002-2018 data from Wprost magazine.

Turning to the results for our main predictors, we find that neither of the three political connection variables is consistently related to the size of the largest fortunes in Poland. This is in contrast with results for Ukraine obtained by Markus and Charnysh (2017), who found a substantial wealth premium for the plutocrats who participated in privatization. This seems to be a direct consequence of stark differences in how the privatization processes were implemented in Poland and Ukraine. In Ukraine, privatization was dominated by insiders, 
former members of the nomenklatura or politically-connected oligarchs, while in Poland the process was much more transparent, controlled and inclusive (see, e.g., Hartwell 2016). On the other hand, Markus and Charnysh (2017) showed that political connections in the form of holding government position or financing political parties are not associated with a higher wealth of Ukrainian oligarchs. Our findings concerning the effect of political connections on wealth level differ also from those of Lamberova and Sonin (2018) who found large positive wealth premium for Russian business elite of being in the "inner circle" of President Vladimir Putin.

Our analysis is consistent with the recent results of Ivlevs et al. (2019), who show that in Visegrad countries (Poland, Slovakia, Czech Republic and Hungary) having links with Communist parties before 1989 is not associated with entrepreneurial attempts or business successes after the fall of communism. ${ }^{16}$ They also found evidence for negative self-selection among the persons with links to Communist parties in the sense that these persons tended to have fewer features associated with entrepreneurship (such as motivation, openness to risk, etc). Overall, Ivlevs et al. (2019) concluded that it is likely that business persons in Visegrad countries after the turn to the market economy did not have to rely on political connections, but rather on their abilities and past entrepreneurial experience under socialism. These conclusions are consistent with our results, but it should be borne in mind that the sample of Ivlevs et al. (2019) covers all business persons, while ours is restricted only to those with the largest fortunes. Moreover, contrary to the suggestions of Ivlevs et al. (2019), we do not find evidence in our sample that running a business already under socialism translates in a market economy setting into entrepreneurial success in terms of higher wealth level.

\subsection{Political connections and mobility on the rich lists}

Although political connections seem to be unrelated to the size of fortunes in our sample, they could have an impact on changes in the relative position of the multimillionaires on the rich lists. In particular, it could be that the position of politically connected rich persons is more stable on the list or that they experience higher probability of advancing on the list. To explore these possibilities in detail, we follow Korom et al. (2017) is estimating regression models with three supplemental dummy dependent variables capturing overall mobility (yearly difference

\footnotetext{
${ }^{16}$ Their results for the broader sample of Central and Eastern Europe and post-Soviet countries show that persons with links to former Communist parties had a higher chance to start a business after 1989, but also that these businesses did not have a higher likelihood of survival (as compared to businesses of people with no links to Communist parties).
} 
in ranking between the current and previous year), as well as upward (downward) mobility defined as movements in the Wprost ranking which are larger than the median of all yearly upward (downward) moves on a given yearly list. The independent variables include those studied in modelling wealth levels, but we add also log of wealth and an indicator variable indicating if people dropped off the list because they died.

Table 2 presents results on the determinants of overall mobility on the rich list. All models suggest that higher wealth is associated with more mobility of the multimillionaires. According to the FEF models, there is significantly more mobility for the rich having their fortunes originated in resource-related and financial sectors. All models unanimously show that the relationship between political connections and mobility is insignificant. However, it is worth noting that for the FEF models the coefficients on Security Service variable is highly negative and only marginally insignificant (with $p$-values of $0.10-0.11$ ) ${ }^{17}$ In future research, it would be worthwhile to gather more comprehensive data (across both persons and time) and verify the hypothesis that Polish multimillionaires who were the former Security Service informants or members of the Communist party face significantly higher risks of falling in the ranking in year-to-year transitions.

Only a few other papers study mobility and related phenomena on the rich lists. Markus and Charnysh (2017) show that in Ukraine political connections in the form of holding a state office before becoming super-rich result in less resilient wealth in the sense that they are associated with negative year-to-year changes in business wealth. On the other hand, they found that direct political party financing by oligarchs has a positive impact on the oligarchs' business wealth resilience. This marks one of the key differences in the extent of the economic and political power of the multimillionaires in Poland and Ukraine. The regulation of funding to political parties has been much stricter in Poland than in Ukraine and, in particular, it banned financing from corporate donors, introduced public funding of the parties and demanded financial reporting (Casal Bértoa and Walecki 2014). These institutional reforms significantly limited the possibility for the rich in Poland to defend their wealth through direct financing of political parties. We were not able to find news from reliable media sources about the illegal financing of parties in Poland.

\footnotetext{
${ }^{17}$ Random effects models and the OLS models also produce estimates on the Security Service coefficients with $p$ values within the range from 0.10 to 0.14 .
} 
Table 2. Determinants of the mobility of the rich in Poland

\begin{tabular}{|c|c|c|c|c|c|c|}
\hline & \multicolumn{2}{|c|}{ Cross-section } & \multicolumn{4}{|c|}{ Panel } \\
\hline & (1) & (2) & (3) & (4) & (5) & (6) \\
\hline & OLS & OLS & $\begin{array}{l}\text { Random } \\
\text { effects }\end{array}$ & $\begin{array}{l}\text { Random } \\
\text { effects }\end{array}$ & $\begin{array}{l}\text { Filtered } \\
\text { fixed } \\
\text { effects }\end{array}$ & $\begin{array}{l}\text { Filtered } \\
\text { fixed } \\
\text { effects }\end{array}$ \\
\hline \multirow[t]{2}{*}{ Log wealth } & $3.858^{* * *}$ & $4.369^{* * *}$ & $4.981 * * *$ & $5.240^{* * *}$ & $16.03 * * *$ & $19.16^{* * *}$ \\
\hline & $(0.588)$ & $(0.709)$ & $(0.684)$ & $(0.801)$ & (1.583) & $(1.841)$ \\
\hline \multirow[t]{2}{*}{ Privatized company } & -1.504 & -1.763 & -1.519 & -1.852 & 4.765 & 1.386 \\
\hline & $(1.501)$ & $(1.598)$ & $(1.716)$ & $(1.746)$ & (4.197) & $(9.003)$ \\
\hline \multirow[t]{2}{*}{ Political connection } & -0.266 & -0.266 & -0.723 & -0.617 & -4.383 & -7.869 \\
\hline & $(1.296)$ & $(1.459)$ & (1.607) & (1.719) & (7.605) & $(9.415)$ \\
\hline \multirow[t]{2}{*}{ Security Service } & -1.970 & -2.229 & -2.476 & -2.698 & -9.373 & -10.323 \\
\hline & $(1.320)$ & $(1.441)$ & (1.607) & $(1.662)$ & $(5.976)$ & $(6.305)$ \\
\hline \multirow[t]{2}{*}{ Self-made } & $3.241^{* *}$ & $3.102^{* *}$ & $4.000 * *$ & $3.324^{* *}$ & $20.55^{* * *}$ & 12.205 \\
\hline & $(1.417)$ & $(1.480)$ & $(1.738)$ & $(1.658)$ & $(5.762)$ & $(18.085)$ \\
\hline \multirow[t]{2}{*}{ Started under socialism } & -0.392 & -0.409 & -0.243 & -0.402 & $7.136^{* * *}$ & 3.493 \\
\hline & $(0.790)$ & $(0.844)$ & $(0.900)$ & $(0.921)$ & $(2.653)$ & $(9.113)$ \\
\hline \multirow[t]{2}{*}{ Age } & -0.023 & -0.135 & -0.034 & -0.151 & $-1.807 * *$ & -1.658 \\
\hline & $(0.234)$ & $(0.235)$ & $(0.264)$ & $(0.252)$ & $(0.768)$ & $(1.507)$ \\
\hline \multirow[t]{2}{*}{ Age squared } & -0.000 & 0.001 & -0.001 & 0.001 & 0.008 & 0.011 \\
\hline & $(0.002)$ & $(0.002)$ & $(0.002)$ & $(0.002)$ & $(0.007)$ & $(0.008)$ \\
\hline \multirow[t]{2}{*}{ Female } & $1.360^{*}$ & 1.251 & $1.781 * *$ & 1.406 & $6.480^{*}$ & 4.133 \\
\hline & $(0.775)$ & $(0.817)$ & $(0.902)$ & $(0.899)$ & (3.437) & $(5.299)$ \\
\hline \multirow[t]{2}{*}{ Higher education } & -0.131 & -0.046 & -0.052 & -0.035 & 2.227 & 1.669 \\
\hline & $(0.850)$ & $(0.897)$ & $(0.953)$ & $(0.967)$ & (2.673) & (3.387) \\
\hline \multirow[t]{2}{*}{ Resource related } & $-5.529^{* * * *}$ & $-5.976^{* * *}$ & $-6.738 * * *$ & $-7.158^{* * *}$ & $9.404 * *$ & $5.279^{*}$ \\
\hline & $(1.459)$ & $(1.901)$ & (1.680) & (2.149) & $(4.342)$ & (2.917) \\
\hline \multirow[t]{2}{*}{ New sectors } & 0.279 & 0.336 & -0.106 & 0.140 & 4.916 & -1.620 \\
\hline & (1.109) & $(1.244)$ & (1.338) & $(1.421)$ & $(5.534)$ & $(5.183)$ \\
\hline \multirow[t]{2}{*}{ Non-traded sectors } & -0.837 & -1.008 & -1.021 & -1.178 & $11.937 * *$ & $9.289^{*}$ \\
\hline & $(0.861)$ & $(0.905)$ & $(0.944)$ & $(0.965)$ & $(5.394)$ & $(4.747)$ \\
\hline \multirow[t]{2}{*}{ Financial sectors } & $-2.506^{* *}$ & $-2.783^{* *}$ & $-2.919 * *$ & $-3.087^{* *}$ & $11.99 * * *$ & $9.303 * * *$ \\
\hline & $(1.023)$ & $(1.107)$ & (1.196) & $(1.231)$ & (4.393) & (2.940) \\
\hline \multirow[t]{2}{*}{ GDP per capita growth } & -0.415 & $-3.420^{*}$ & -0.448 & $-4.081^{* *}$ & $-0.898 * * *$ & 0.973 \\
\hline & $(0.273)$ & $(1.858)$ & $(0.273)$ & $(1.887)$ & $(0.272)$ & $(6.216)$ \\
\hline \multirow[t]{2}{*}{ Deceased } & -8.262 & -8.936 & -7.466 & -8.569 & -1.672 & -1.641 \\
\hline & $(5.883)$ & $(5.420)$ & $(5.687)$ & $(5.239)$ & (2.290) & $(2.775)$ \\
\hline \multirow[t]{2}{*}{ Constant } & $-23.95^{* * *}$ & -11.702 & $-30.32 * * *$ & -13.743 & - & - \\
\hline & (7.804) & $(10.120)$ & $(8.835)$ & $(10.569)$ & - & - \\
\hline Time fixed effects & No & Yes & No & Yes & No & Yes \\
\hline Observations & 1401 & 1401 & 1401 & 1401 & 1401 & 1401 \\
\hline Number of the rich & 206 & 206 & 206 & 206 & 206 & 206 \\
\hline \multicolumn{7}{|c|}{$\begin{array}{l}\text { Notes: Standard errors clustered by person in parentheses. }{ }^{*} p<0.1,{ }^{* *} p<0.05,{ }^{* * *} p<0.01 \text {. The } \\
\text { dependent variable is mobility defined as the difference in wealth ranking between the current and the } \\
\text { previous year. See Section } 3 \text { for definitions of other variables. "Traded sectors" is the reference category } \\
\text { for the business sector variable. OLS stands for ordinary least squares. }\end{array}$} \\
\hline
\end{tabular}


Table 3. Determinants of the upward mobility of the rich in Poland (marginal effects)

\begin{tabular}{|c|c|c|c|c|c|c|}
\hline & \multicolumn{2}{|c|}{ Cross-section } & \multicolumn{4}{|c|}{ Panel } \\
\hline & (1) & (2) & (3) & (4) & (5) & (6) \\
\hline & Logit & Logit & $\begin{array}{l}\text { Random } \\
\text { effects }\end{array}$ & $\begin{array}{l}\text { Random } \\
\text { effects }\end{array}$ & $\begin{array}{l}\text { Filtered } \\
\text { fixed } \\
\text { effects }\end{array}$ & $\begin{array}{l}\text { Filtered } \\
\text { fixed } \\
\text { effects }\end{array}$ \\
\hline \multirow[t]{2}{*}{ Log wealth } & -0.023 & -0.025 & -0.023 & -0.025 & $0.200 * * *$ & $0.246^{* * *}$ \\
\hline & $(0.015)$ & $(0.016)$ & $(0.019)$ & $(0.022)$ & $(0.030)$ & $(0.033)$ \\
\hline \multirow[t]{2}{*}{ Privatized company } & -0.021 & -0.011 & -0.021 & -0.011 & 0.040 & -0.079 \\
\hline & $(0.047)$ & $(0.045)$ & $(0.047)$ & $(0.045)$ & $(0.091)$ & $(0.203)$ \\
\hline \multirow[t]{2}{*}{ Political connection } & $-0.092^{* *}$ & $-0.087^{* *}$ & $-0.092^{* *}$ & $-0.087^{*}$ & $-0.195^{*}$ & $-0.288^{*}$ \\
\hline & $(0.045)$ & $(0.044)$ & $(0.046)$ & $(0.045)$ & $(0.104)$ & $(0.155)$ \\
\hline \multirow[t]{2}{*}{ Security Service } & -0.033 & -0.030 & -0.033 & -0.030 & -0.126 & -0.144 \\
\hline & $(0.043)$ & $(0.041)$ & $(0.043)$ & $(0.042)$ & $(0.122)$ & $(0.130)$ \\
\hline \multirow[t]{2}{*}{ Self-made } & $0.173^{* * *}$ & $0.184^{* * *}$ & $0.173^{* * *}$ & $0.184^{* * *}$ & $0.371 * * *$ & 0.086 \\
\hline & $(0.042)$ & $(0.043)$ & $(0.042)$ & $(0.043)$ & $(0.095)$ & $(0.402)$ \\
\hline \multirow[t]{2}{*}{ Started under socialism } & -0.012 & -0.005 & -0.012 & -0.005 & $0.096 *$ & -0.042 \\
\hline & $(0.024)$ & $(0.024)$ & $(0.024)$ & $(0.023)$ & $(0.055)$ & $(0.205)$ \\
\hline \multirow[t]{2}{*}{ Age } & -0.004 & -0.009 & -0.004 & -0.009 & -0.007 & 0.002 \\
\hline & $(0.011)$ & $(0.010)$ & $(0.011)$ & $(0.010)$ & $(0.019)$ & $(0.034)$ \\
\hline \multirow[t]{2}{*}{ Age squared } & 0.000 & 0.000 & 0.000 & 0.000 & -0.000 & 0.000 \\
\hline & $(0.000)$ & $(0.000)$ & $(0.000)$ & $(0.000)$ & $(0.000)$ & $(0.000)$ \\
\hline \multirow[t]{2}{*}{ Female } & 0.020 & 0.020 & 0.020 & 0.020 & 0.110 & 0.032 \\
\hline & $(0.025)$ & $(0.025)$ & $(0.025)$ & $(0.025)$ & $(0.068)$ & $(0.116)$ \\
\hline \multirow[t]{2}{*}{ Higher education } & 0.038 & $0.043^{*}$ & 0.038 & $0.043^{*}$ & $0.079 *$ & 0.047 \\
\hline & $(0.024)$ & $(0.023)$ & $(0.024)$ & $(0.024)$ & $(0.047)$ & $(0.070)$ \\
\hline \multirow[t]{2}{*}{ Resource related } & $-0.150^{* * *}$ & $-0.147^{* * *}$ & $-0.150^{* * * *}$ & $-0.147^{* * *}$ & 0.003 & -0.045 \\
\hline & $(0.048)$ & $(0.054)$ & $(0.049)$ & $(0.056)$ & $(0.164)$ & $(0.151)$ \\
\hline \multirow[t]{2}{*}{ New sectors } & -0.020 & -0.028 & -0.020 & -0.028 & -0.059 & -0.155 \\
\hline & $(0.041)$ & $(0.041)$ & $(0.042)$ & $(0.042)$ & $(0.184)$ & $(0.168)$ \\
\hline \multirow[t]{2}{*}{ Non-traded sectors } & 0.003 & 0.004 & 0.003 & 0.004 & 0.145 & 0.111 \\
\hline & $(0.025)$ & $(0.025)$ & $(0.025)$ & $(0.025)$ & $(0.182)$ & $(0.164)$ \\
\hline \multirow[t]{2}{*}{ Financial sectors } & -0.021 & -0.028 & -0.021 & -0.028 & 0.051 & 0.007 \\
\hline & $(0.031)$ & $(0.030)$ & $(0.031)$ & $(0.030)$ & $(0.165)$ & $(0.149)$ \\
\hline \multirow[t]{2}{*}{ GDP per capita growth } & $-0.016^{* *}$ & 0.029 & $-0.016^{* *}$ & 0.029 & $-0.023 * * *$ & 0.086 \\
\hline & $(0.007)$ & $(0.048)$ & $(0.007)$ & $(0.049)$ & $(0.008)$ & $(0.137)$ \\
\hline \multirow[t]{2}{*}{ Deceased } & - & - & - & - & -0.047 & -0.050 \\
\hline & - & - & - & - & $(0.137)$ & $(0.138)$ \\
\hline Time fixed effects & No & Yes & No & Yes & No & Yes \\
\hline Observations & 1397 & 1397 & 1397 & 1397 & 1401 & 1401 \\
\hline Number of the rich & 206 & 206 & 206 & 206 & 206 & 206 \\
\hline \multicolumn{7}{|c|}{$\begin{array}{l}\text { Notes: Standard errors clustered by person in parentheses. }{ }^{*} p<0.1,{ }^{* *} p<0.05,{ }^{* * *} p<0.01 \text {. The } \\
\text { dependent variable is upward mobility defined as a dummy variable that takes the value of } 1 \text { if a person } \\
\text { experienced an upward move in the Wprost ranking larger than the median of all yearly upward moves. } \\
\text { See Section } 3 \text { for definitions of other variables. "Traded sectors" is the reference category for the } \\
\text { business sector variable. }\end{array}$} \\
\hline
\end{tabular}


Table 4. Determinants of the downward mobility of the rich in Poland (marginal effects)

\begin{tabular}{|c|c|c|c|c|c|c|}
\hline & \multicolumn{2}{|c|}{ Cross-section } & \multicolumn{4}{|c|}{ Panel } \\
\hline & (1) & (2) & (3) & (4) & (5) & (6) \\
\hline & Logit & Logit & $\begin{array}{l}\text { Random } \\
\text { effects }\end{array}$ & $\begin{array}{l}\text { Random } \\
\text { effects }\end{array}$ & $\begin{array}{l}\text { Filtered } \\
\text { fixed } \\
\text { effects }\end{array}$ & $\begin{array}{l}\text { Filtered } \\
\text { fixed } \\
\text { effects }\end{array}$ \\
\hline \multirow[t]{2}{*}{ Log wealth } & $-0.241^{* * *}$ & $-0.304^{* * *}$ & $-0.241^{* * *}$ & $-0.304^{* * *}$ & $-0.393 * * *$ & $-0.472 * * *$ \\
\hline & $(0.015)$ & $(0.019)$ & $(0.019)$ & $(0.025)$ & $(0.035)$ & $(0.038)$ \\
\hline \multirow[t]{2}{*}{ Privatized company } & -0.065 & -0.059 & -0.065 & -0.059 & $-0.186^{*}$ & 0.031 \\
\hline & $(0.045)$ & $(0.048)$ & $(0.045)$ & $(0.048)$ & $(0.112)$ & $(0.224)$ \\
\hline \multirow[t]{2}{*}{ Political connection } & $-0.111^{* * *}$ & $-0.104^{* * *}$ & $-0.111^{* * * *}$ & $-0.104^{* * * *}$ & -0.088 & 0.082 \\
\hline & $(0.030)$ & $(0.030)$ & $(0.031)$ & $(0.031)$ & $(0.181)$ & $(0.225)$ \\
\hline \multirow[t]{2}{*}{ Security Service } & 0.021 & 0.047 & 0.021 & 0.047 & 0.157 & 0.185 \\
\hline & $(0.041)$ & $(0.046)$ & $(0.044)$ & $(0.050)$ & $(0.138)$ & $(0.141)$ \\
\hline \multirow[t]{2}{*}{ Self-made } & 0.013 & 0.046 & 0.013 & 0.046 & $-0.370 * * *$ & 0.153 \\
\hline & $(0.044)$ & $(0.041)$ & $(0.049)$ & $(0.042)$ & $(0.138)$ & $(0.424)$ \\
\hline \multirow[t]{2}{*}{ Started under socialism } & 0.006 & 0.012 & 0.006 & 0.012 & $-0.137 * *$ & 0.120 \\
\hline & $(0.021)$ & $(0.021)$ & $(0.021)$ & $(0.021)$ & $(0.068)$ & $(0.216)$ \\
\hline \multirow[t]{2}{*}{ Age } & -0.007 & -0.004 & -0.007 & -0.004 & $0.054 * * *$ & 0.031 \\
\hline & $(0.009)$ & $(0.008)$ & $(0.009)$ & $(0.009)$ & $(0.018)$ & $(0.035)$ \\
\hline \multirow[t]{2}{*}{ Age squared } & 0.000 & 0.000 & 0.000 & 0.000 & $-0.000 * *$ & $-0.000 * *$ \\
\hline & $(0.000)$ & $(0.000)$ & $(0.000)$ & $(0.000)$ & $(0.000)$ & $(0.000)$ \\
\hline \multirow[t]{2}{*}{ Female } & -0.024 & -0.007 & -0.024 & -0.007 & $-0.140 *$ & -0.005 \\
\hline & $(0.026)$ & $(0.026)$ & $(0.028)$ & $(0.026)$ & $(0.081)$ & $(0.131)$ \\
\hline \multirow[t]{2}{*}{ Higher education } & 0.013 & 0.012 & 0.013 & 0.012 & -0.015 & 0.047 \\
\hline & $(0.023)$ & $(0.023)$ & $(0.023)$ & $(0.023)$ & $(0.060)$ & $(0.074)$ \\
\hline \multirow[t]{2}{*}{ Resource related } & -0.009 & 0.089 & -0.009 & 0.089 & -0.195 & -0.061 \\
\hline & $(0.197)$ & $(0.370)$ & $(0.197)$ & $(0.370)$ & $(0.239)$ & $(0.205)$ \\
\hline \multirow[t]{2}{*}{ New sectors } & -0.053 & $-0.069^{* *}$ & -0.053 & $-0.069^{* *}$ & -0.390 & -0.208 \\
\hline & $(0.033)$ & $(0.029)$ & $(0.039)$ & $(0.033)$ & $(0.267)$ & $(0.248)$ \\
\hline \multirow[t]{2}{*}{ Non-traded sectors } & 0.022 & 0.028 & 0.022 & 0.028 & -0.203 & -0.116 \\
\hline & $(0.023)$ & $(0.024)$ & $(0.024)$ & $(0.024)$ & $(0.269)$ & $(0.246)$ \\
\hline \multirow[t]{2}{*}{ Financial sectors } & 0.018 & 0.015 & 0.018 & 0.015 & -0.261 & -0.182 \\
\hline & $(0.027)$ & $(0.029)$ & $(0.029)$ & $(0.030)$ & $(0.242)$ & $(0.203)$ \\
\hline \multirow[t]{2}{*}{ GDP per capita growth } & $0.015^{* *}$ & $0.175^{* * * *}$ & $0.015^{* *}$ & $0.175^{* * *}$ & $0.027 * * *$ & -0.132 \\
\hline & $(0.007)$ & $(0.041)$ & $(0.007)$ & $(0.041)$ & $(0.007)$ & $(0.143)$ \\
\hline \multirow[t]{2}{*}{ Deceased } & 0.022 & 0.095 & 0.022 & 0.095 & 0.047 & 0.069 \\
\hline & $(0.226)$ & $(0.174)$ & $(0.226)$ & $(0.174)$ & $(0.177)$ & $(0.168)$ \\
\hline Time fixed effects & No & Yes & No & Yes & No & Yes \\
\hline Observations & 1401 & 1401 & 1401 & 1401 & 1401 & 1401 \\
\hline Number of the rich & 206 & 206 & 206 & 206 & 206 & 206 \\
\hline \multicolumn{7}{|c|}{$\begin{array}{l}\text { Notes: Standard errors clustered by person in parentheses. }{ }^{*} p<0.1,{ }^{* *} p<0.05,{ }^{* * *} p<0.01 \text {. The } \\
\text { dependent variable is downward mobility defined as a dummy variable that takes the value of } 1 \text { if a } \\
\text { person experienced a downward move in the Wprost ranking larger than the median of all yearly } \\
\text { downward moves. See Section } 3 \text { for definitions of other variables. "Traded sectors" is the reference } \\
\text { category for the business sector variable. }\end{array}$} \\
\hline
\end{tabular}

Korom et al. (2017) provide a detailed analysis of mobility on the Forbes 400 list of the US rich over the period 1982-2013. They found that the persons that inherited their wealth lose on average three ranks on the list as compared to the self-made multimillionaires. Our estimations, except for the FEF model with time fixed effects, also show that the self-made rich on average 
improve their ranking position from year to year. ${ }^{18}$ The investigation of mobility is further extended in Tables 3-4, which show results from the models estimating determinants of upward and downward mobility (indicators pointing out if annual changes in the ranking are greater than the median changes). We observe that having political connections is associated with 20$30 \%$ lower probability (columns 5-6 in Table 3) of advancing in the ranking (upward mobility). It seems, therefore, that even if political connections helped amass outstanding wealth in Poland, they contributed less to gaining an advantage over competitors and outranking them on the rich list. Political connections are negatively related also to downward mobility according to logit and random effects models, but not according to our preferred FEF modes. Other variables related to political connections (privatization-related origins of wealth and being a former Security Service informant or communist party member) are not significantly related to any type of mobility.

\subsection{Do political connections help to stay on the rich list?}

In this section, we extend the analysis of mobility on the rich list to account for the factors that are associated with persistence on the rich list over time or dropping off the list. One can drop out of the rich list due to several things: her stock assets may lose its value, he may have made an unfortunate decision investing in a new business, she may still perform well but finds herself in a more competing environment and simply others have outperformed her, or even he could have died and thus naturally drop out. As shown in section 3.1, on average $16 \%$ of the list members drop out each year, while the mean number of years a person stay on the list is 6.4 in a 17-year period. Table 5 presents the results of a Cox proportional hazards model with multiple failures with "failure" meaning that a person dropped off the list. Since it is possible to drop out and come back a year or several years later, we need to handle multiple failures (see Section 4 for details). The factors that increase or decrease the probability of falling off the list include the covariates used in modelling mobility as well as a yearly percentage change in mean wealth of all list members. This latter factor accounts for the possibility that a person is dropping off the list because she was outcompeted by other multimillionaires. We present results sequentially adding our political connection variables (models 2-4) to the basic specification (model 1).

\footnotetext{
${ }^{18}$ The same types of models suggest also that the self-made multimillionaires have a higher chance of upward mobility (see Table 3).
} 
Table 5. Cox regression on hazards of dropping off the rich list in Poland

\begin{tabular}{|c|c|c|c|c|}
\hline & (1) & (2) & (3) & (4) \\
\hline \multirow[t]{2}{*}{ Age } & 1.053 & 1.053 & 1.061 & 1.116 \\
\hline & (0.67) & $(0.67)$ & $(0.76)$ & (1.38) \\
\hline \multirow{2}{*}{ Age squared } & 0.999 & 0.999 & 0.999 & 0.999 \\
\hline & $(-0.72)$ & $(-0.72)$ & $(-0.82)$ & $(-1.43)$ \\
\hline \multirow[t]{2}{*}{ Female } & 0.906 & 0.905 & 0.912 & 0.926 \\
\hline & $(-0.31)$ & $(-0.31)$ & $(-0.28)$ & $(-0.24)$ \\
\hline \multirow[t]{2}{*}{ Higher education } & 1.067 & 1.069 & 1.061 & 1.174 \\
\hline & $(0.29)$ & $(0.29)$ & $(0.26)$ & $(0.71)$ \\
\hline \multirow[t]{2}{*}{ Self-made } & 0.985 & 0.983 & 0.939 & 0.797 \\
\hline & $(-0.03)$ & $(-0.04)$ & $(-0.13)$ & $(-0.52)$ \\
\hline \multirow[t]{2}{*}{ Started under socialism } & 1.023 & 1.020 & 1.036 & 1.097 \\
\hline & (0.11) & (0.09) & (0.16) & $(0.43)$ \\
\hline \multirow[t]{2}{*}{ Log wealth } & $0.0193^{* * *}$ & $0.0194^{* * *}$ & $0.0245^{* * *}$ & $0.0275^{* * *}$ \\
\hline & $(-3.25)$ & $(-3.20)$ & $(-2.85)$ & $(-2.83)$ \\
\hline \multirow[t]{2}{*}{ Log wealth squared } & $1.291^{* * *}$ & $1.290^{* * *}$ & $1.267^{* *}$ & $1.253^{* *}$ \\
\hline & (2.95) & $(2.88)$ & $(2.50)$ & $(2.46)$ \\
\hline \multirow[t]{2}{*}{ Resource related } & $3.726^{* * *}$ & $3.738^{* * *}$ & $3.342^{* * *}$ & $3.836^{* * *}$ \\
\hline & $(3.41)$ & $(3.45)$ & $(3.12)$ & (3.45) \\
\hline \multirow{2}{*}{ New sectors } & 0.734 & 0.733 & 0.736 & 0.700 \\
\hline & $(-0.44)$ & $(-0.44)$ & $(-0.43)$ & $(-0.50)$ \\
\hline \multirow[t]{2}{*}{ Non-traded sectors } & 0.967 & 0.965 & 0.971 & 1.040 \\
\hline & $(-0.15)$ & $(-0.16)$ & $(-0.13)$ & $(0.17)$ \\
\hline \multirow[t]{2}{*}{ Financial sectors } & 1.025 & 1.027 & 1.044 & 1.101 \\
\hline & (0.09) & (0.10) & (0.16) & $(0.35)$ \\
\hline \multirow[t]{2}{*}{ Change in mean wealth (yearly) } & 0.584 & 0.587 & 0.605 & 0.764 \\
\hline & $(-0.93)$ & $(-0.92)$ & $(-0.86)$ & $(-0.45)$ \\
\hline \multirow[t]{2}{*}{ GDP per capita growth } & $1.343^{* * *}$ & $1.341^{* * *}$ & $1.341^{* * *}$ & $1.358^{* * *}$ \\
\hline & $(4.33)$ & $(4.05)$ & $(4.02)$ & $(4.12)$ \\
\hline \multirow[t]{2}{*}{ Deceased } & $2.155^{*}$ & $2.172^{*}$ & $2.171^{*}$ & $2.118^{*}$ \\
\hline & (1.67) & (1.66) & (1.65) & (1.70) \\
\hline \multirow[t]{2}{*}{ Privatized company } & & 0.980 & 0.957 & 1.021 \\
\hline & & $(-0.07)$ & $(-0.14)$ & $(0.07)$ \\
\hline \multirow[t]{2}{*}{ Political connection } & & & 1.313 & 1.280 \\
\hline & & & $(0.68)$ & $(0.72)$ \\
\hline Security Service & & & & $\begin{array}{c}1.794^{* *} \\
(2.16)\end{array}$ \\
\hline Observations & 1677 & 1677 & 1677 & 1656 \\
\hline Number of the rich & 255 & 255 & 255 & 255 \\
\hline
\end{tabular}

Notes: The table shows exponentiated coefficients (hazard ratios). Z-statistics based on standard errors clustered by person are shown in parentheses. ${ }^{*} p<0.1,{ }^{* * *} p<0.05,{ }^{* * *} p<0.01$. See Section 3 for definitions of all variables.

Source: Own calculations using 2002-2018 data from Wprost magazine.

The results show that across all specifications the estimated hazard ratios are significantly higher than one for having wealth origins in the resource-related sector, GDP per capita growth, and, not surprisingly, the dummy variable indicating death. The fact that having a fortune originated in the resources-related sector is associated with increased risk of dropping off the rich list is linked to the decreasing business significance of these sectors at the expense of the financial and new technology sectors (see Figure 3). Decreased likelihood of survival 
due to higher GDP growth may mean that the process of replacement of less efficient business competitors by more efficient ones is intensified in periods of economic booms. Not surprisingly, the level of log wealth is (non-linearly) associated with improved survival on the rich list. Contrary to the findings of Korom et al. (2017) for American billionaires, we obtained that personal characteristics such as age, gender or education do not seem to affect the relative chances of survival in the Polish rich list.

Turning to our political connection variables, we observe that only the coefficient on Security Service variable is statistically significant. This means that being a former Security Service informant or communist party member is associated with a 79\% higher risk of dropping off the rich list. It seems, therefore, that having political connections of different kinds has not been a protective factor for Polish multimillionaires over the last two decades. On the contrary, we find that having links in the past with the communist party or communist secret police decreases the likelihood of preserving the outstanding position among the richest Poles. One can hypothesize that even if political connections were crucial in helping some of the Polish multimillionaires to amass their wealth early in the process of transition to market economies (in the 1990s), it is likely that gradually they have become less valuable as informal networks of former communists became weaker and the competition from younger business persons, not linked in any way to communist institutions, became fiercer.

Our results on the relationship between political connections and survival on the ranking of the rich in Poland can be compared to those for Ukraine and Russia. Markus and Charnysh (2017) have found that political connections in the form of participating in privatization process or being a "red director", as well as direct strategies of defending wealth (holding a government position) are not associated with being listed longer among oligarchs in Ukraine. On the other hand, they found that financing political parties or owing media assets is linked to a longer presence among the richest oligarchs. We do not find such effects for Poland. In the case of Russia, it is well-known that political connections, in general, did not protect oligarchs from authoritarian expropriation (Guriev and Rachinsky 2008, Braguinsky 2009). Braguinsky (2009) shows in a detailed way that many Russian oligarchs who were formerly members of communist nomenklatura were expropriated, especially between 1998 and 2003. He also shows that having political connections with the present ruler is crucial for securing property rights for plutocrats under an oligarchic and authoritarian system. Therefore, persistence among the richest Russians is almost surely positively correlated with political connections understood as having a political pact with the current authoritarian ruler that ensures oligarchs' property rights. 
This kind of relationship does not have to be present in a democratic country, such as Poland, where rule of law is much stronger.

\subsection{Summary and limitations}

Our results show that measurable political connections are not associated with a wealth level of Polish multimillionaires, but are negatively linked to the upward mobility of the rich and increase the likelihood of dropping off the rich list. These findings suggest that political connections were not a barrier to amassing wealth or a factor restricting market competition among the most successful business persons in Poland over the last two decades. We did not find evidence that political connections in Poland led to the emergence of uncompetitive crony capitalism or an oligarchic system that would be detrimental to further economic development. However, there are some limitations to the present study. Since there is no reliable quantitative data on the wealth of Polish super-rich in the 1990s, we were unable to model factors that determined the entry of new members on the list. Political connections were likely to facilitate such an entry, especially just after the transition to market economy started in the early 1990s. Secondly, we managed to collect data only on certain kinds of political connections, which are relatively easy to measure. However, more informal connections probably exist that can have an impact on the likelihood of success or failure of the Polish multimillionaires. We leave this possibility for future research. Third, our data set contains only information on the wealth of rich list members and those with lower wealth levels are left out of the analysis. To account for this, we re-analysed our basic models using truncated regression approach with a truncation value set to the lowest wealth value in our sample. ${ }^{19} \mathrm{We}$ obtained results quantitatively similar to those presented in the paper (detailed results are available upon request). In particular, our political connection variables were not significantly related to higher wealth. Finally, our results could be influenced by reverse causation or omitted variables. We attempted to adjust for these problems by using panel data and fixed effects panel regression models, as well as by defining our political connection variables as predetermined. However, this approach only partially corrects for the problem of omitted variables, and, in particular, do not account for omitted variables (including informal political connections) that could vary over time. For this reason, our results should be interpreted cautiously in terms of associations rather than causality.

\footnotetext{
${ }^{19}$ For a description of the truncated regression model see, e.g., Greene (2018, pp. 918-924).
} 


\section{Conclusions}

Extreme wealth is increasing rapidly in both in the advanced and in emerging economies. Political connections are one of the main channels through which individuals become superrich, especially in post-socialist or emerging markets (Freund 2016). When it limits competition and results in large efficiency losses, crony capitalism can be detrimental to the country's economic development. Evidence also shows that politically connected wealth inequality is negatively related to economic growth (Bagchi and Svejnar 2015). In this paper, we have studied whether political connections help the super-wealthy Poles to become even more wealthy and sustain their privileged position. We have used newly collected data set on Polish multimillionaires observed over 2002-2018. Surprisingly, we found that political connections do not help in raising fortunes those who are already super-rich. In addition, cronyism in Poland lowers the probability of upward mobility in the ranking of the rich, while being a former associate of communist institutions dramatically increases the likelihood of dropping off the list of the richest Poles. These results shows that cronyism is much less pervasive in Poland than in some other post-communist countries such as Russia or Ukraine. It seems that this state of affairs in Poland has been determined by multiple causes - lack of large natural resource endowments, dispersed political power with largely fragmented party system and parties' inability to monopolize the state, relatively high quality of political and economic institutions in Poland, credible prospects of the EU accession as a driver of further institutional reforms, political consensus on limiting power of big business and the importance of small business and strong middle class, and others. Future research is needed to determine which institutions and country characteristics contribute most to limiting the ability of cronies to defend and expand their wealth over their super-wealthy competitors.

\section{References}

Acemoglu, Daron, and James A. Robinson. 2012. Why Nations Fail: The Origins of Power, Prosperity, and Poverty. New York: Crown Books.

Bach, Stefan, Andreas Thiemann, and Aline Zucco. 2019. "Looking for the Missing Rich: Tracing the Top Tail of the Wealth Distribution." International Tax and Public Finance 26 (6): 1234-58. https://doi.org/10.1007/s10797-019-09578-1.

Bagchi, Sutirtha, and Jan Svejnar. 2015. "Does Wealth Inequality Matter for Growth? The Effect of Billionaire Wealth, Income Distribution, and Poverty." Journal of Comparative Economics 43 (3): 505-30. https://doi.org/10.1016/j.jce.2015.04.002.

Bagchi, Sutirtha, Jan Svejnar, and Kendra Bischoff. 2016. "Does Wealth Distribution and the Source of Wealth Matter for Economic Growth? Inherited v. Uninherited Billionaire Wealth and Billionaires' Political Connections." In Inequality and Growth: Patterns and 
Policy, 163-94. London: Palgrave Macmillan. https://doi.org/10.1057/9781137554598_5.

Berend, Ivan T. 2011. Od Bloku Sowieckiego Do Unii Europejskiej. Transformacja Ekonomiczna i Społeczna Europy Środkowo-Wschodniej Od 1973 Roku. Wydawnictwo Uniwersytetu Jagiellońskiego.

Braguinsky, Serguey. 2009. "Postcommunist Oligarchs in Russia: Quantitative Analysis." Journal of Law and Economics 52 (2): 307-49. https://doi.org/10.1086/589656.

Candau, Fabien, and Tchapo Gbandi. 2019. "Trade and Institutions: Explaining Urban Giants." Journal of Institutional Economics 15 (6): 1017-35. https://doi.org/10.1017/s1744137419000328.

Canterbery, E. Ray, and E. Joe Nosari. 1985. "The Forbes Four Hundred: The Determinants of Super-Wealth." Southern Economic Journal 51 (4): 1073-83. https://doi.org/10.2307/1058378.

Capehart, Kevin W. 2014. "Wealth Inequality Revisited: Lessons from the 400 Wealthiest Americans." 18th Annual Conference of the Research Network Macroeconomics and Macroeconomic Policies. Berlin.

Casal Bértoa, Fernando, and Marcin Walecki. 2014. "Regulating Polish Politics: 'Cartel' Parties in a Non-Collusive Party System." East European Politics 30 (3): 330-50. https://doi.org/10.1080/21599165.2014.933415.

Earle, John S., Scott Gehlbach, Anton Shirikov, and Solomiya Shpak. 2019. "Preventing Predation: Oligarchs, Obfuscation, and Political Connections." Becker Friedman Institute. https://doi.org/10.2139/ssrn.3501060.

Fidrmuc, Jarko, and Lidwina Gundacker. 2017. "Income Inequality and Oligarchs in Russian Regions: A Note." European Journal of Political Economy 50: 196-207. https://doi.org/10.1016/j.ejpoleco.2017.09.005.

Freund, Caroline. 2016. Rich People Poor Countries: The Rise of Emerging-Market Tycoons and Their Mega Firms. Peterson Institute for International Economics.

Greene, William H. 2018. Econometric Analysis. 8th ed. New York: Pearson.

Guriev, Sergei, and Andrei Rachinsky. 2005. "The Role of Oligarchs in Russian Capitalism." Journal of Economic Perspectives 19 (1): 131-50. https://doi.org/10.1257/0895330053147994.

_. 2008. "The Evolution of Personal Wealth in the Former Soviet Union and Central and Eastern Europe." In Personal Wealth from a Global Perspective, edited by James B. Davies, 134-49. Oxford: Oxford University Press.

Hartwell, Christopher A. 2016. Two Roads Diverge: The Transition Experience of Poland and Ukraine. Cambridge: Cambridge University Press.

Hausman, Jerry A., and William E. Taylor. 1981. "Panel Data and Unobservable Individual Effects." Econometrica 49 (6): 1377. https://doi.org/10.2307/1911406.

Havrylyshyn, Oleh. 2006. Divergent Paths in Post-Communist Transformation. Capitalizm for All or Capitalism for the Few? Palgrave Macmillan.

Hay, Iain, and Jonathan Beaverstock. 2016. Handbook on Wealth and the Super-Rich. Cheltenham: Edward Elgar. https://doi.org/10.4337/9781783474042.

Hoff, Karla, and Joseph E. Stiglitz. 2004. "After the Big Bang? Obstacles to the Emergence of the Rule of Law in Post-Communist Societies." American Economic Review 94 (3): 753 63. https://doi.org/10.1257/0002828041464533.

Hurst, Erik, Ming Ching Luoh, and Frank P. Stafford. 1998. "The Wealth Dynamics of American Families, 1984-94." Brookings Papers on Economic Activity, no. 1: 267-337. https://doi.org/10.2307/2534673.

IMF. 2000. "World Economic Outlook. October 2000: Focus on Transition Economies." Washington, DC.

Ivlevs, Artjoms, Milena Nikolova, and Olga Popova. 2019. "Former Communist Party 
Membership and Present-Day Entrepreneurship in Central and Eastern Europe.” IZA DP No. 12761. Bonn. www.iza.org.

Kaplan, Steven N, and Joshua Rauh. 2013. "It's the Market: The Broad-Based Rise in the Return to Top Talent." Journal of Economic Perspectives 27 (3): 35-56. https://doi.org/10.1257/jep.27.3.35.

Keister, Lisa A. 2014. "The One Percent." Annual Review of Sociology 40 (1): 347-67. https://doi.org/10.1146/annurev-soc-070513-075314.

Klass, Oren S., Ofer Biham, Moshe Levy, Ofer Malcai, and Sorin Solomon. 2006. "The Forbes 400 and the Pareto Wealth Distribution." Economics Letters 90 (2): 290-95. https://doi.org/10.1016/j.econlet.2005.08.020.

Klevmarken, N. Anders, Joseph P. Lupton, and Frank P. Stafford. 2003. "Wealth Dynamics in the 1980s and 1990s: Sweden and the United States." Journal of Human Resources 38 (2): 322-53. https://doi.org/10.2307/1558747.

Korom, Philipp, Mark Lutter, and Jens Beckert. 2017. "The Enduring Importance of Family Wealth: Evidence from the Forbes 400, 1982 to 2013." Social Science Research 65: 7595. https://doi.org/10.1016/j.ssresearch.2017.03.002.

Lamberova, Natalia, and Konstantin Sonin. 2018. "Economic Transition and the Rise of Alternative Institutions: Political Connections in Putin's Russia." Economics of Transition 26 (4): 615-48. https://doi.org/10.1111/ecot.12167.

Markus, Stanislav, and Volha Charnysh. 2017. "The Flexible Few: Oligarchs and Wealth Defense in Developing Democracies." Comparative Political Studies 50 (12): 1632-65. https://doi.org/10.1177/0010414016688000.

Medeiros, Marcelo, and Pedro Hg Ferreira De Souza. 2015. "The Rich, the Affluent and the Top Incomes." Current Sociology Review 63 (6): 869-95. https://doi.org/10.1177/0011392114551651.

Mihályi, Péter, and Iván Szelényi. 2019. Rent-Seekers, Profits, Wages and Inequality: The Top 20\%. Springer International Publishing.

Monday, Christopher. 2017. "Privatization to Putinization: The Genesis of Russia's Hobbled Oligarchy." Communist and Post-Communist Studies 50 (4): 303-17. https://doi.org/10.1016/j.postcomstud.2017.09.004.

Neumayer, Eric. 2004. "The Super-Rich in Global Perspective: A Quantitative Analysis of the Forbes List of Billionaires." Taylor \& Francis 11 (13): 793-96. https://doi.org/10.1080/1350485042000258283.

Ogwang, Tomson. 2011. "Power Laws in Top Wealth Distributions: Evidence from Canada." Empirical Economics 41 (2): 473-86. https://doi.org/10.1007/s00181-010-0384-5.

Pesaran, M. Hashem, and Qiankun Zhou. 2018. "Estimation of Time-Invariant Effects in Static Panel Data Models." Econometric Reviews 37 (10): 1137-71. https://doi.org/10.1080/07474938.2016.1222225.

Piątkowski, Marcin. 2018. Europe's Growth Champion: Insights from the Economic Rise of Poland. Oxford University Press.

Piketty, Thomas. 2014. Capital in the Twenty-First Century. Cambridge, MA: The Belknap Press of Harvard University Press.

Powdthavee, Nattavudh, Richard V Burkhauser, and Jan Emmanuel De Neve. 2017. "Top Incomes and Human Well-Being: Evidence from the Gallup World Poll." Journal of Economic Psychology 62: 246-57. https://doi.org/10.1016/j.joep.2017.07.006.

Prinz, Aloys. 2016. "Do Capitalistic Institutions Breed Billionaires?" Empirical Economics 51 (4): 1319-32. https://doi.org/10.1007/s00181-015-1058-0.

Roland, Gerard. 2018. "The Evolution of Post-Communist Systems: Eastern Europe vs. China." Economics of Transition 26 (4): 589-614. https://doi.org/10.1111/ecot.12164.

Siegfried, John J., and Alison Roberts. 1991. "How Did the Wealthiest Britons Get so Rich?" 
Review of Industrial Organization 6 (1): 19-32. https://doi.org/10.1007/BF00427998.

Siegfried, John J., and David K. Round. 1994. "How Did the Wealthiest Australians Get So Rich?" Review of Income and Wealth 40 (2): 191-204. https://doi.org/10.1111/j.14754991.1994.tb00058.x.

Treisman, Daniel. 2016. "Russia's Billionaires.” American Economic Review 106 (5): 236-41. Vermeulen, Philip. 2016. "Estimating the Top Tail of the Wealth Distribution." American Economic Review 106 (5): 646-50. https://doi.org/10.1257/aer.p20161021.

- 2018. "How Fat Is the Top Tail of the Wealth Distribution?" Review of Income and Wealth 64 (2): 357-87. https://doi.org/10.1111/roiw.12279.

Wei, Lee-Jen, Danyu Y. Lin, and Lisa Weissfeld. 1989. "Regression Analysis of Multivariate Incomplete Failure Time Data by Modeling Marginal Distributions." Journal of the American Statistical Association 84 (408): 1065-73. https://doi.org/10.1080/01621459.1989.10478873.

World Bank Group. 2017. Lessons from Poland, Insights for Poland: A Sustainable and Inclusive Transition to High Income Status. World Bank, Washington, DC.

Zucman, Gabriel. 2019. "Global Wealth Inequality.” Annual Review of Economics 11 (1): 10938. https://doi.org/10.1146/annurev-economics-080218-025852. 


\section{Appendix. Supplementary tables and figures}

Table A1 Descriptive statistics for variables used in this study

\begin{tabular}{lccccc}
\hline & $\mathrm{N}$ & Mean & Std Dev. & Min & Max \\
\hline Dependent variables: & & & & & \\
Logarithm of Wealth & 1,700 & 6.4 & .87 & 4.8 & 9.7 \\
Mobility & 1,434 & -.77 & 15 & -71 & 73 \\
Upward Mobility & 1,434 & .19 & .39 & 0 & 1 \\
Downward Mobility & 1,434 & .23 & .42 & 0 & 1 \\
& & & & & \\
\hline Independent variables: & & & & & \\
Political Connection & 1,700 & .072 & .26 & 0 & 1 \\
Security Service & 1,674 & .096 & .29 & 0 & 1 \\
Privatized Company & 1,700 & .059 & .24 & 0 & 1 \\
Started under Socialism & 1,677 & .5 & .5 & 0 & 1 \\
Self-made & 1,695 & .92 & .27 & 0 & 1 \\
Industry 1: Resource Related & 1,700 & .021 & .14 & 0 & 1 \\
Industry 2: New Sectors & 1,700 & .095 & .29 & 0 & 1 \\
Industry 3: Non-Traded Sectors & 1,700 & .26 & .44 & 0 & 1 \\
Industry 4: Financial Sectors & 1,700 & .18 & .38 & 0 & 1 \\
Industry 5: Traded Sectors & 1,700 & .44 & .5 & 0 & 1 \\
Female & 1,700 & .14 & .34 & 0 & 1 \\
Age & 1,697 & 53 & 9.3 & 18 & 82 \\
Bachelor or more & 1,700 & .67 & .47 & 0 & 1 \\
GDP per capita growth rate & 1,700 & 4 & 1.5 & 1.5 & 7.1 \\
Mean Wealth Change & 1,700 & .053 & .17 & -.33 & .46 \\
Died & 1,700 & .0029 & .054 & 0 & 1 \\
\hline
\end{tabular}

Note: The number of observations for mobility variables equals 1,434 because each of 266 persons in the study has these variables missing in his or her first year on the rich list. 